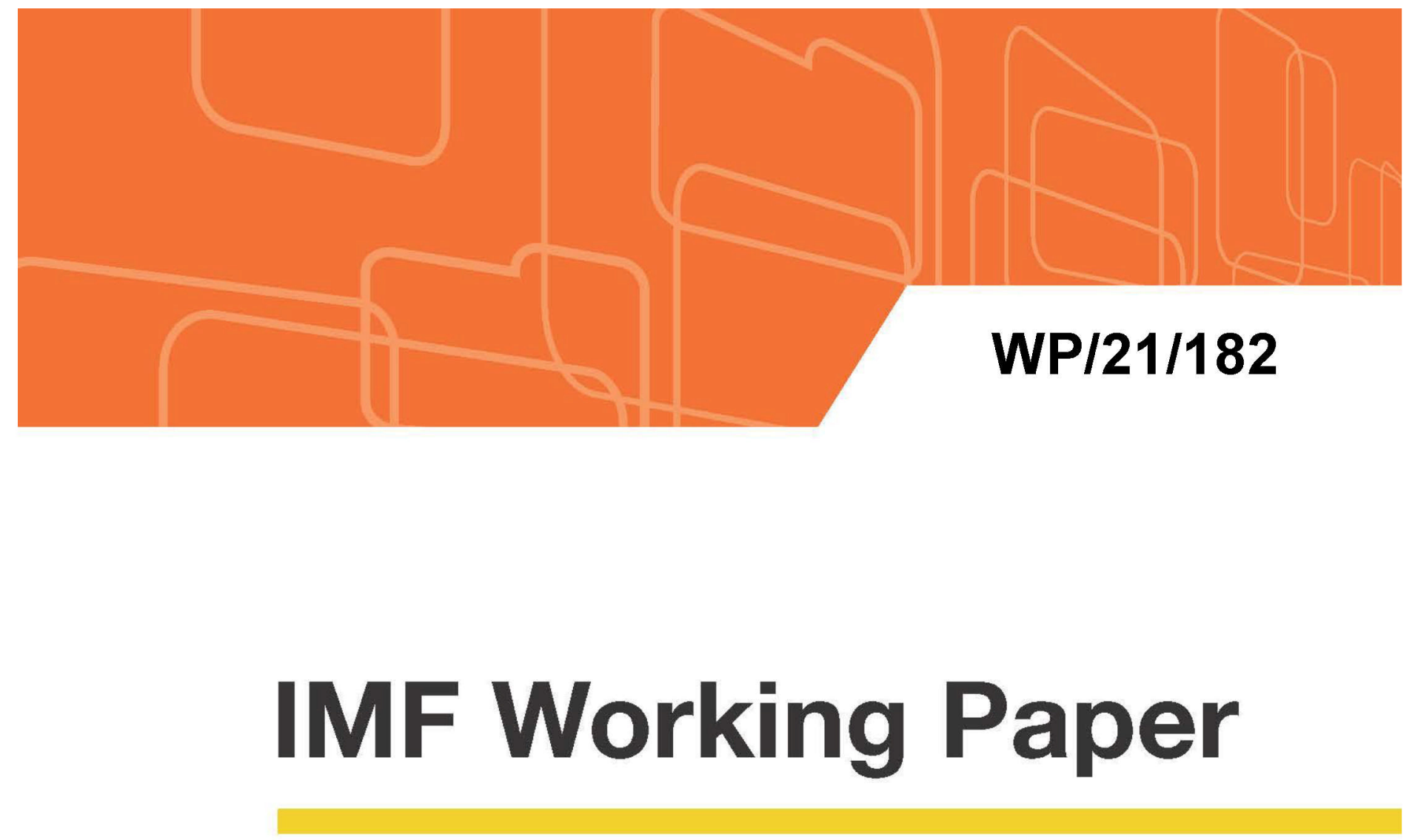

\title{
Addressing Spillovers from Prolonged U.S. Monetary Policy Easing
}

by Stephen G. Cecchetti, Machiko Narita, Umang Rawat and Ratna Sahay

IMF Working Papers describe research in progress by the author(s) and are published to elicit comments and to encourage debate. The views expressed in IMF Working Papers are those of the author(s) and do not necessarily represent the views of the IMF, its Executive Board, or IMF management.

$$
\text { I N T E R N A T I O N A L M O NETAR Y FU N D }
$$




\title{
IMF Working Paper
}

Monetary and Capital Markets Department

\author{
Addressing Spillovers from Prolonged U.S. Monetary Policy Easing \\ Prepared by Stephen G. Cecchetti, Machiko Narita, Umang Rawat and Ratna Sahay ${ }^{1}$
}

July 2021

\section{IMF Working Papers describe research in progress by the author(s) and are published to elicit comments and to encourage debate. The views expressed in IMF Working Papers are those of the author(s) and do not necessarily represent the views of the IMF, its} Executive Board, or IMF management.

\begin{abstract}
There is growing recognition that prolonged monetary policy easing of major economies can have extraterritorial spillovers, driving up financial system leverage in other countries. When faced with such a rise of threats to financial stability, what can countries do? Specifically, is there a role for macroprudential tools, capital controls or foreign exchange intervention in safeguarding financial stability from risks arising externally? We examine the efficacy of these policy interventions by exploring whether preemptive or reactive policy interventions can mitigate such risks. Using a sample of 950 bank and nonbank financial firms across 28 non-U.S. economies over the past two decades, we show that if policymakers are able to implement policies prior to an additional consecutive decline in U.S. interest rates, financial institutions do not increase their leverage by as much as they otherwise would. By contrast, it is more difficult to counter the spillovers with reactive policy interventions. In practice, however, policymakers need to remain cautious about the timing of preventative tightening, especially when their economies face large negative shocks such as a pandemic.
\end{abstract}

JEL Classification Numbers: E52, E58, F38, G21, G23, G28

Keywords: Spillovers, prolonged monetary policy easing, financial stability, macroprudential policies, foreign-exchange intervention, capital flow management measures.

Author's E-Mail Address: cecchett@,brandeis.edu, MNarita@imf.org, URawat@,imf.org, and RSahay@,imf.org.

\footnotetext{
${ }^{1}$ Cecchetti is Rosen Family Chair in International Finance at the Brandeis International Business School, Research Associate at the NBER, and Research Fellow at the CEPR; Narita is Senior Economist in the Monetary and Capital Markets Department at the IMF; Rawat is Economist in the Asia and Pacific Department at the IMF; and Sahay is Senior Advisor on Gender in the Office of the Managing Director at the IMF. We thank Apoorv Bhargava for outstanding research assistance, Luis Brandao-Marques, Gaston Gelos, Erlend Nier, and Wenyue Yang for sharing their codes on policy shocks, Tobias Adrian, Futoshi Narita and many other colleagues at the IMF for helpful discussions and comments, as well as Sara Durrani and Joanna Zaffaroni for production assistance. Cecchetti's disclosure statement is available here. The views expressed in this paper are those of the authors and do not necessarily represent those of the IMF.
} 


\section{CONTENTS}

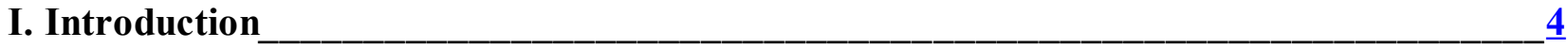

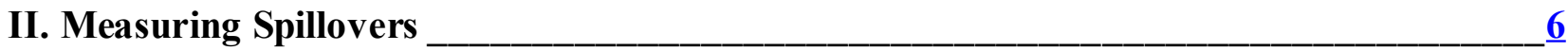

III. Domestic Policies To Address Risks From Spillovers________ 10

A. Mitigating The Impact Of Spillovers On Leverage ___ 13

B. Preventing The Impact Of Spillovers On Leverage___ 17

IV. Conclusion ___ _ _

Appendix: Data Sources And Definitions _______

References___________ $\underline{32}$

\section{Figures}

1. Leverage Ratio Of Financial Firms By Industry Group

2. Macroprudential And Capital Flow Management Measures In Place

3. Foreign Exchange Interventions

\section{Tables}

1. Impact Of Domestic And U.S. Monetary Policy Easing On Financial Firm Leverage $\underline{9}$

2. Mitigation Policies

3. Prevention Policies

\section{Appendix}

1. Data Sources And Definitions 


\section{INTRODUCTION}

"When monetary policy in large countries is extremely and unconventionally accommodative, capital flows into recipient countries tend to increase local leverage; this is not just due to the direct effect of cross-border banking flows but also the indirect effect, as the appreciating exchange rate and rising asset prices, especially of real estate, make it seem that borrowers have more equity than they really have." Raghuram Rajan, Governor of the Reserve Bank of India, April 2014.

Central bankers in small open economies have always questioned the sufficiency of monetary policy as the sole tool for countering external financial shocks. Recently, researchers have joined the debate, concluding that a number of economies are strongly in fluenced by changing global financial conditions, with U.S. monetary policy playing a central role in shaping global financial conditions. ${ }^{1}$ Recent theoretical contribtuions suggest that, in the presence of frictions and externalities, assuring monetary au tonomy and safeguarding financial stability may require more than just traditional interest rate too $1 .{ }^{2}$ For authorities to achieve their stabilization objectives, they may need to avail themselves of some combination of macroprudential policies, capital flow management tools (CFMs), and foreign exchange intervention (FXI). As we survey the landscape, we see a broad cross-section of countries employing many of these measures. ${ }^{3}$ The joint usage of monetary policy, FXI, CFMs, and macroprudential tools have been labeled the "Integrated Policy Framework", or IPF, in recent work by the International Monetary Fund on updating its macroeconomic framework. ${ }^{4}$

In this paper, we examine the efficacy of these complementary policy interventions. To do so, we first document the size and importance of spillovers of prolonged U.S. policy easing on financial firms' leverage; and then proceed to study whether preemptive or reactive policy interventions are effective in mitigating the spillovers. In the first step of our analysis, using a sample of 950 bank and nonbank financial firms across 28 non-U.S. economies, we confirm the results of Cecchetti, Mancini-Griffoli, Narita and Sahay (2020). Namely, prolonged U.S. monetary policy easing spills over to other countries, driving up financial system leverage; and that these spillovers are larger than the impact of domestic policy easing. That is, a sustained reduction in U.S. interest rates increases bank and nonbank financial firms' leverage by more than an equivalent change in the path of domestic interest rates.

Finding evidence that U.S. monetary policy has a large extraterritorial impact surely comes as no surprise to country authorties, managers of private financial and nonfinancial firms, and market

\footnotetext{
${ }^{1}$ See, for example, Rey (2013), Obstfeld (2015), Passari and Rey (2015), Choi et al. (2017), Arregui et al. (2018), and Avdjiev et al. (2019).

2 See Farhi and Werning (2016), Ghosh et al. (2016), Korinek and Sandri (2016), Arce et al. (2019), Cavallino (2019), Adrian et al. (2020), Basu et al. (2020), and Fanelli and Straub (2020).

${ }^{3}$ For example, Ghosh et al. (2017), Mano and Sgherri (2020), and Pasricha (2020) show that various policies respond to capital flow shocks or financial stability concerns, by estimating policy reaction functions in emerging market economies. See also Finger and Lopez Murphy (2019) and IMF (2020).

${ }^{4}$ See https://blogs.imf.org/2020/07/13/toward-an-integrated-policy-framework-for-open-economies/.
} 
participants. The global dominance of the dollar means that monetary policy easing in the United States has an impact not only on exchange rates, but on prices of dollar-denominated commodities, cross-border financial flows and the price of risk. Faced with changes in the prices of virtually all assets, financial firms everywhere reoptimize their portfolios.

What can authorities do if prolonged easing of U.S. monetary policy drives up leverage, increasing domestic financial stability risks? To address this question, we turn to quarterly data from 1998 to 2018, and examine whether countries can use macroprudential, capital flow management, or foreign exchange intervention policies to mitigate the impact of prolonged U.S. policy easing on their financial institutions' leverage. Here, there are two cases. In one, policymakers act to prevent the impact of the spillover before it comes, and in the second, they move contemporaneously.

Our results suggest that preemptive actions are more effective than reactive ones. That is, when policymakers are able to implement mitigating policies prior to further decline in U.S. interest rates, financial institutions do not increase their leverage by as much as they otherwise would. By contrast, waiting has little mitigating impact on the increase in financial risk that spillovers bring. This is the pattern for all policy tools that we examine.

Our study contributes to the rich and growing empirical literature that examines policies that aim to manage international spillovers. Rey (2013) and many others document significant international spillovers from U.S. monetary policy on financial stability via capital flows, exchange rates, and financial firms leverage. ${ }^{5}$ At the same time, a number of studies investigate the efficacy of various policy tools in countering the spillovers. ${ }^{6}$ One conclusion from this literature is that the impact of policy depends on economic and structural conditions.

To these existing findings, we add that, when the objective is to contain the spillovers of U.S. policy on financial institution leverage, preemption is more effective than reaction. We see our results as analogous to those of Klein (2012), who conclues that having capital flow management measures in place for long periods tends to be more effective than episodic implementation that is aimed at addressing specific vulnerabilities that arise.

Of course, policy always reflects a variety of factors in addition to those we consider. For example, when faced with a large negative real shock, such as the ongoing pandemic, tightening of prudential policies seems unlikely to be productive or appropriate at this time. Even though our analysis suggests that such preventative measures may have medium-term benefits, it would be important for policy-makers to also consider the exact timing of prudential polices.

\footnotetext{
${ }^{5}$ For example, see Chen et al. (2014), Albagli et al. (2019), and Kalemli-Özcan (2019) for the spillovers via risk perceptions and exchange rates; and Bruno and Shin (2015a, b), Barroso et al. (2016), Morais et al. (2019), Cecchetti et al. (2020), for thos e via cross-border credits and financial firms' leverage.

${ }^{6}$ For the literature survey on policy effects, see Galati and Moessner (2018) and Araujo et al. (2020) for macroprudential poli cy; Erten et al. (2020) and Rebucci and Ma (2019) for capital flow management measures; and Sarno and Taylor (2001) and Chamon et al. (2019) for foreign exchange intervention.
} 
Following this brief introduction, in Section 2 we reproduce the results of Cecchetti et al. (2020) for our expanded data set that include more countries and a longer time period. We confirm their conclusion that the impact of prolonged U.S. monetary policy on financial firms' leverage is typically larger than that of domestic monetary policy easing. In Section 3, we address the core question of this paper: Are domestic policy tools to either prevent or mitigate effective in addressing the risks arising when prolonged U.S. monetary policy easing drives up financial firm's leverage? The final section provides a brief conclusion.

\section{Measuring Spillovers}

We begin by establishing that the results in Cecchetti et al. (2020) hold for our expanded data set. Briefly, we collect quarterly information from 1998 Q1 to 2019Q3 on 950 financial firms in 20 non-U.S. advanced and 8 emerging market economies (Brazil, Colombia, Malaysia, Mexico, Russia, South Africa, Thailand, and Turkey). ${ }^{7}$ These are divided into six industry groups based on the Global Industry Classification Standard provided by Morgan Stanley Capital International (MSCI) and Standard \& Poor's categories: commercial banks; insurance companies; real estate firms; asset managers; investment banks; and a residual category, "other."8 (See Appendix I.A. for more information about our sample.)

We measure financial stability risks using financial firm leverage. We compute the market-value version of leverage, which is defined as the market value of equity plus the book value of liabilities divided by the market value of equity. We use this measure because of its relationship with systemic risks. Here, we point to two related results in the literature. First, likely because market prices reflect firm's prospects and intangible assests more quickly and accurately, Campbell et al. (2008) find that market-value leverage has stronger explanatory power than bookvalue leverage in explaining financial distress. Second, Acharya et al. $(2014,2017)$ find that a market-value measure of leverage is a useful input to systemic risk indicators that track the results of macroprudential stress tests. ${ }^{9}$

\footnotetext{
${ }^{7}$ Cecchetti et al. (2020) study 613 non-U.S. firms from 20 countries over the period 1998Q1 to 2014Q4. So, we have 327 additional firms, covering 8 added countries, over 5 more years.

8 "Banks" are firms that derive their revenue primarily from conventional banking operations. "Insurance companies" include life and non-life insurers, as well as reinsurance companies. "Investment banks" are firms that primarily engage in investment banking and brokerage services. "Asset management" are entities that invest third-party funds. "Real estate firms" consist of real estate investment trusts (REITs), as well as real estate management and development firms. And "other" includes holding companies, consumer finance firms, and firms that provide specialized or diversified financial services.
}

${ }^{9}$ Adrian et al. $(2014,2016)$ argue that book-value leverage is useful in assessing the lending capacity of financial intermediaries. 


\section{Figure 1. Leverage Ratio of Financial Firms by Industry Group}

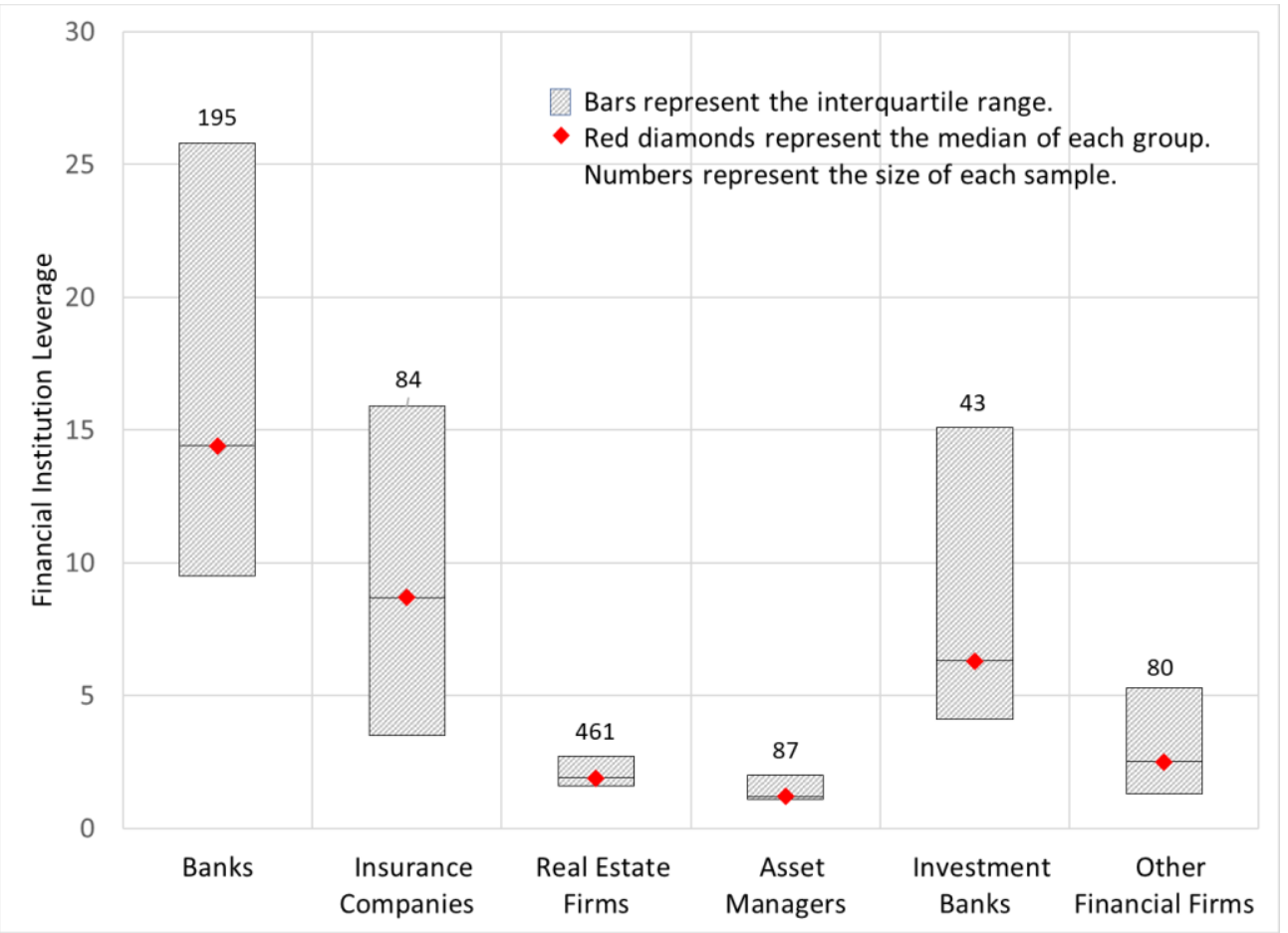

Sources: Datastream, Worldscope, and authors'calculations.

Notes: Computations are based on an unbalanced panel data for 950 publicly listed financial firms in 28 non-U.S. countries from 1998Q1-2019Q3. To avoid over-rep resentation from firms with more observations, we report industry percentiles from firm-level medians. The statistics are not weighted by asset size. Leverage is measured as the market value of equity plus the book value of liabilities divided by the market value of equity

Figure 1 reports summary information for our sample. The bars represent the interquartile range and the red diamonds $(\diamond)$ are the median for leverage in each industry group. We also report the number of firms in each category above each bar. Note that banks tend to have both the highest leverage, and the broadest range - in the sample, the median is 14.4 and the interquartile range varies from 9.5 to 25.8 . By contrast, asset managers have very low leverage in a very narrow range - the median is 1.2 and the interquartile range is less than 1 .

To examine the spillover impact of prolonged or sustained U.S. monetary easing on non-U.S. financial firms' leverage, we follow Cecchetti et al. (2020) and measure the duration of U.S. monetary policy easing $\left(D_{t}^{U S}\right)$ at time $t$ as below:

$$
D_{t}^{U S}=\left\{\begin{array}{cc}
D_{t-1}^{U S}+1 & \text { if } \vec{l}_{t}^{U S}<\vec{t}_{t-1}^{U S} \\
0 & \text { Otherwise }
\end{array}\right.
$$

This duration variable counts the number of consecutive quarters with a decline in the trend component of the interest rate $i_{t}^{U S}$, measured as the moving average: $\bar{l}_{t}^{U S}=\frac{1}{8} \sum_{\tau=1}^{8} i_{t-\tau+1}^{U S}$. In this way we focus on the trend component, removing temporary movements in the interest rate. For 
the interest rate $i_{t}^{U S}$, we use the two-year sovereign bond yield, as it reflects both conventional and unconventional monetary policies. ${ }^{10}$ Analogously, we compute the duration of domestic monetary policy easing $\left(D_{k t}\right)$ for each country $k$ in our sample. ${ }^{11}$

It is important to note that the duration variables are based on consecutive easings (i.e., successive rate declines). As such, we are not measuring whether the stance of monetary policy is more or less accomodative. For example, authorities could be seeking to ease financial conditions by reducing their policy rate, but where the market rates remain above the natural rate of interest so their stance is tight. Instead, our focus is on declines in observable market interest rates. This means both that our duration measure is not a measure of policy stance and that movements could reflect various factors other than changes in monetary policy. ${ }^{12}$

Turning to policy spillovers, we estimate the impact of prolonged monetary policy easing, both domestic and U.S., on financial institution leverage using the following equation:

$$
\ln \left(\mathrm{Y}_{\mathrm{ikt}}\right)=\alpha_{0}+\alpha_{1} \mathrm{D}_{\mathrm{kt}}+\alpha^{\mathrm{US}} \mathrm{D}_{\mathrm{t}}^{\mathrm{US}}+\beta \mathrm{X}_{\mathrm{kt}-1}+\mathrm{c}_{\mathrm{i}}+\varepsilon_{\mathrm{ikt}}
$$

where $Y_{i k t}$ is leverage for firm $i$ in country $k$ at time $t ; D_{k t}$ and $D_{t}^{U S}$ are the duration of domestic and U.S. monetary policy easing, respectively; $\mathrm{c}_{\mathrm{i}}$ is a firm fixed effect; and $\mathrm{X}_{\mathrm{kt}-1}$ is a vector of lagged macroeconomic control variables that includes year-on-year GDP growth, equity price growth, equity volatility and the sovereign's bond rating. This specification allows us to interpret the coefficient of the duration as a semi-elasticity. For example, $\alpha^{U S}$ measures the percentage change in financial firms' leverage for each additional one-quarter of U.S. monetary policy easing.

Table 1 reports the results of estimating equation (2). Looking at the details, first note that we report the marginal effect of a one-quarter increase in the duration of policy easing evaluated at the median of the data. ${ }^{13}$ As a result, these numbers are in the same units as the raw leverage numbers. For example, we estimate that a one-quarter easing increases bank leverage in a

\footnotetext{
${ }^{10}$ Two-year sovereign yield is used as an indicator of monetary policy in many studies covering the periods with unconventional monetary policy (e.g., Swanson and Williamson, 2014, Gertler and Karadi, 2015, Gilchrist et al. 2015, Hanson and Stein, 2015, Ambler and Rumler, 2019), while it is fair to say that the extent of monetary policy transmission to two-year yield may vary across time periods and countries (e.g., Rogers et al. 2014).

${ }^{11}$ Cecchetti et al. (2020) discuss alternative measures of the duration of monetary policy easing, including a measure based on the cumulative declines in the interest rate during the sustained easing, and report that results are similar.

12 There are also challenges in measuring the stance of monetary policy. Laubach and Williams (2003) and Holston et al. (2017) emphasize the uncertainty in the estimated natural rate. Also, Taylor type rules require assumptions on unobservable variables, such as the natural interest rate and the output gap, and have various specifications (e.g., Carare and Tchaidze 2005, NikolskoRzhevskyy et al. 2014).

13 To compute the marginal impact of a change in duration on the level of leverage, first rewrite equation (2) as $\mathrm{Y}_{\mathrm{ikt}}=\exp \left(\alpha_{1} D_{k t}+\cdots\right)$. Then take the derivative with respect to $D_{k t}$ to obtain $\left[\partial Y_{i k t} / \partial D_{k t}\right]=\alpha_{1} \exp \left(\alpha_{1} D_{k t}+\cdots\right)=\alpha_{1} Y_{i k t}$, which is the marginal effect. Alternatively, differentiate (2) to obtain $\left(1 / Y_{i k t}\right) d Y_{i k t}=a_{1} d D_{k t}$, so $\left(d Y_{i k t} / d D_{k t}\right)=a_{1} Y_{i k t}$. We evaluate $\alpha_{1} Y_{i k t}$ at the sample median leverage and report the result in the Table. Standard errors are computed using the delta-method, evaluated at this same sample median.
} 
representative country by 0.07 , from 14.4 to 14.5 , an increase that is signific antly different from zero at the 10 percent level. ${ }^{14}$

\begin{tabular}{|c|c|c|c|c|c|c|}
\hline & Banks & $\begin{array}{l}\text { Insurance } \\
\text { Companies } \\
\end{array}$ & $\begin{array}{l}\text { Real Estate } \\
\text { Firms }\end{array}$ & $\begin{array}{c}\text { Asset } \\
\text { Managers }\end{array}$ & $\begin{array}{c}\text { Investment } \\
\text { Banks }\end{array}$ & Other \\
\hline $\begin{array}{l}\text { Impact of Dom. Pol. } \\
\text { Easing }\left(\alpha_{1}\right)\end{array}$ & $\begin{array}{l}0.074 \dagger \\
(0.042)\end{array}$ & $\begin{array}{l}0.039 \dagger \\
(0.021)\end{array}$ & $\begin{array}{c}-0.006 \dagger \\
(0.003)\end{array}$ & $\begin{array}{c}0.000 \\
(0.001)\end{array}$ & $\begin{array}{l}0.064^{* *} \\
(0.022)\end{array}$ & $\begin{array}{c}-0.010 \dagger \\
(0.006)\end{array}$ \\
\hline $\begin{array}{l}\text { Impact of U.S. Pol. } \\
\text { Easing }\left(\alpha^{\cup S}\right)\end{array}$ & $\begin{array}{l}0.131^{* *} \\
(0.045) \\
\end{array}$ & $\begin{array}{l}0.070^{* *} \\
(0.015) \\
\end{array}$ & $\begin{array}{l}0.014^{* *} \\
(0.004) \\
\end{array}$ & $\begin{array}{l}0.004^{* *} \\
(0.002)\end{array}$ & $\begin{array}{l}0.045 \dagger \\
(0.025) \\
\end{array}$ & $\begin{array}{l}0.024^{* *} \\
(0.008) \\
\end{array}$ \\
\hline Median Leverage & 14.441 & 8.750 & 1.940 & 1.249 & 6.272 & 2.512 \\
\hline $\begin{array}{c}\text { Number of } \\
\text { Observations }\end{array}$ & 10,130 & 4,015 & 17,787 & 3,105 & 1,823 & 3,520 \\
\hline $\mathrm{R}^{2}$ & 0.17 & 0.09 & 0.09 & 0.04 & 0.11 & 0.06 \\
\hline \multicolumn{7}{|c|}{$\begin{array}{l}\text { Sources: Bloomberg, Datastream, Haver, WEO, Worldscope, and authors' estimates. } \\
\text { Notes: Estimates, from equation (2), of the marginal effect of one additional quarter of own-country and U.S. monetary } \\
\text { policy easing, evaluated at the sample median (e.g., for domestic duration, it shows } \partial Y / \partial D=\alpha_{1} Y \text {, where } Y \text { is the } \\
\text { sample median of leverage). Standard errors are in parentheses, based on Driscoll and Kraay (1998), which are robust } \\
\text { to heteroscedasticity and cross-sectional and temporal dependences with stationary variables. } \\
\text { ** Significantly different from zero at the } 1 \text { percent level. } \\
\text { * Significantly different from zero at the } 5 \text { percent level. } \\
\text { t Significantly different from zero at the } 10 \text { percent level. }\end{array}$} \\
\hline
\end{tabular}

Overall, we confirm the results first reported in Cecchetti et al. (2020) that prolonged U.S. monetary policy increases financial firms' leverage, and its effects are typically larger than those of domestic monetary policy easing. For example, one quarter of additional U.S. monetary policy easing increases bank leverage by 0.13 - nearly double that of domestic easing, which is 0.07 .15

Evidence of sizable spillover effects from U.S. monetary policy highlights the complex challenge facing many authorities, especially those in small open economies. When a country's business cycle is correlated with that of the United States, domestic monetary policy and spillovers will work together to amplify the swings in financial sector vulnerability. And, when a given country and the United States business cycles are at different stages, domestic authorities may feel the need to counter the impact of U.S. policy.

Other empirical studies provide complementary evidence to support the view that U.S. monetary policy spillovers have financial stability implications across a wide range of countries. For example, Barroso, Pereira da Silva and Soares Sales (2016) conclude that U.S. quantitative easing led to an increase in accumulated gross capital inflows by 2 to 4 percent in Brazil. And, Morais, Peydró, Roldán-Peña and Ruiz (2019) find that monetary policy easing in major advanced

\footnotetext{
${ }^{14}$ To address the possible endogeniety bias in estimating the effect of the duration of sustained easing, Cecchetti et al. (2020) conduct a robustness check with the panel generalized method of moments (GMM) estimator and find that results are similar.

${ }^{15}$ See Table 3 of the earlier paper. We also confirm the earlier results using two alternative measures of risk, the Sharpe ratio and the z-score.
} 
economies softens lending conditions more for high-credit-risk firms in Mexico, suggesting international search-for-yield behavior. The general concern is that U.S. monetary policy actions induce cross-border financial flows that can create financial stability risks in recipient countries.

\section{Domestic Policies to AdDress Risks From SPILlovers}

We now turn to our primary question: Can countries use any domestic policies to mitigate or prevent the spillover effects from prolonged U.S. monetary policy easing?

Recently developed theoretical models demonstrate how, in the presence of financial frictions and externalities, achieving macroeconomic and financial stability objectives may require using policy tools. For example, Farhi and Werning (2016) and Korinek and Sandri (2016) show that macroprudential policies and capital flow management measures (CFMs) can enhance macrofinancial stability by preventing excessive borrowing when private agents do not internalize their collective impact on aggregate demand or asset prices (i.e., when externalities exist). Cavallino (2019) and Fanelli and Straub (2019) conclude that when international financial markets are imperfect, to meet the objective of macro-financial stability, foreign exchange intervention (FXI) should lean against cross-border portfolio flows by accumulating reserves. Basu et al. (2020) show that, depending on country-specific characteristics, optimal stabilization policy requires that authorities use a combination of policies. With this in mind, we examine the efficacy of macroprudential, CFM, and FXI policies in addressing the risks posed by prolonged U.S. monetary policy easing on financial firms' leverage.

Before turning to the estimates, we document the use of these tools in our sample economies. Figure 2 plots the average across countries of the fraction of macroprudential and capital flow management policy instruments in place at any one time. ${ }^{16}$ For the former, we use the annual indices from Cerutti et al. (2017), covering 12 categories of instruments. ${ }^{17}$ For CFMs, we use information on 29 categories of the measures intended to restrict capital inflows that Baba et al. (forthcoming) construct from information in the IMF's Annual Report on Exchange Arrangements and Exchange Restrictions.

\footnotetext{
${ }^{16}$ Please note that information in Figure 2 is based solely on whether indicators are on or off, so it captures introductions an d repeals but not the intensity of the measures. For the regression analysis, we additionally consider other indicators that also capture adjustments in the calibration of the measures, going beyond the broad on/off usage.

17 Of these, 10 measures are institution-based, including capital buffers, exposure limits, and reserve requirements; and 2 measures are borrower-based, including debt-to-income and loan-to-value limits.
} 
Starting with the macroprudential measures, the black line in Figure 2, we see growing use in recent years. Unsurprisingly, the use of these tools increases following the global financial crisis - a fact others document as well. ${ }^{18}$ Note that at the beginning of our sample, roughly 10 percent of the macroprudential instruments were in place. Over the intervening 20 years, the number has gradually risen to 35 percent as more instruments have been introduced. We note that, considered individually, the borrower- and institution-based components of the combined index follow the same pattern.

For CFMs, the usage of inflow measures is relatively low in our sample of 28 countries, while there is heterogeneity across countries. The average fraction of the inflow restrictions in use fluctuates around 20 percent (see the red solid line in Figure 2). However, while we do not distinguish these in the figure, it is worth noting that CFMs are more actively used among emerging market economies. ${ }^{19}$

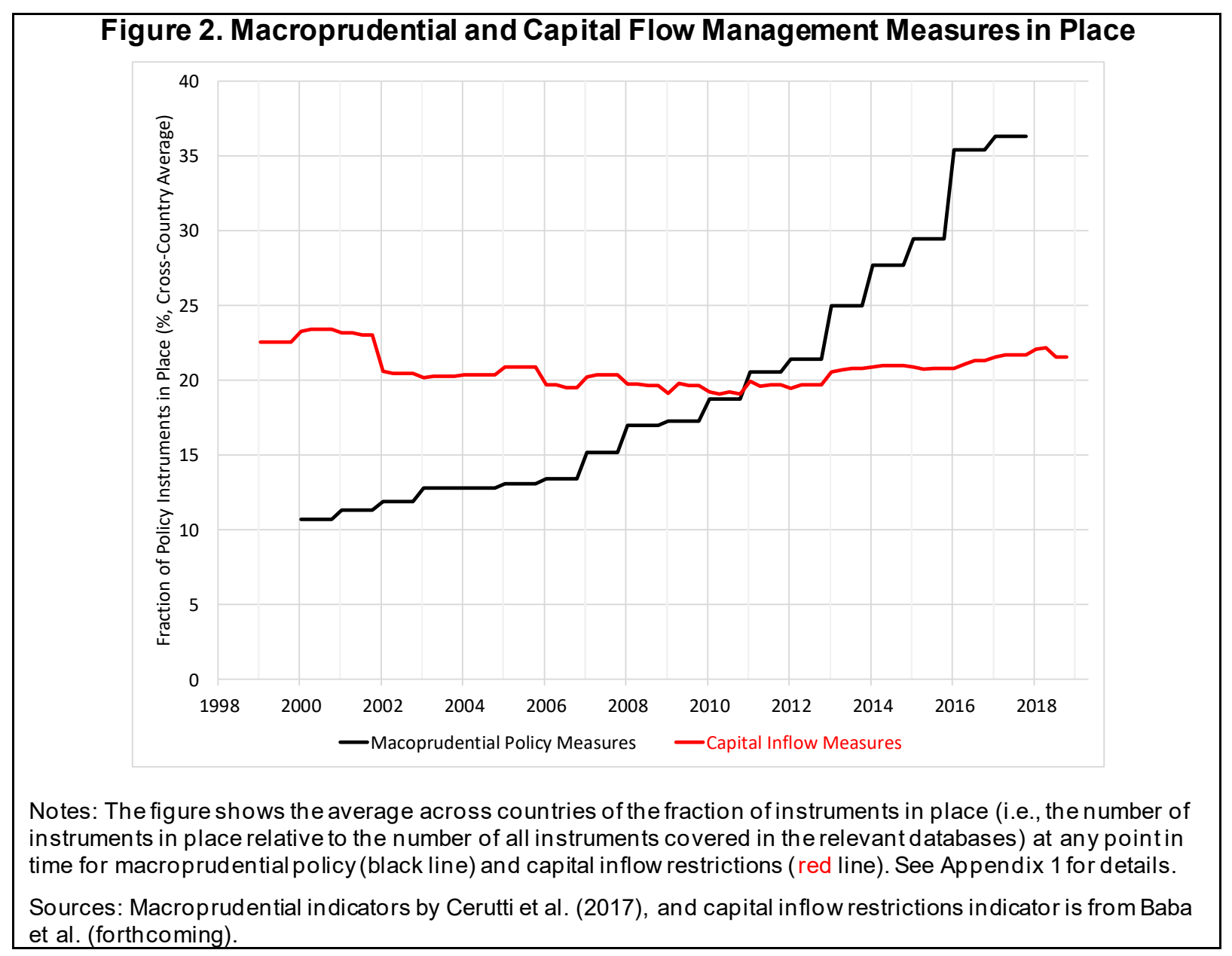

\footnotetext{
${ }^{18}$ For example, see IMF-FSB-BIS (2016), Akinci and Olmstead-Rumsey (2017), and Alam et al. (2019).

${ }^{19}$ See Klein (2012), Fernández et al. (2016), and Erten et al. (2020).
} 
Turning to official FX intervention, while it is common in emerging market economies, the overall frequency in our sample of countries is relatively low. ${ }^{20}$ Focusing on the 12 countries whose FX intervention data are publicly available, Figure 3 reports the number of countries conducting official intervention in each quarter. On average, just one or two countries announce either FX purchases (black bars) or sales (red bars) in a quarter.

Our interest is in the ability of policies to both mitigate and prevent the potentially damaging impact from U.S. monetary policy spillovers on leverage that we documented in Section 2. To study mitigation, we look at the impact of policy shocks that are coincident with U.S. policy easing. To examine prevention, we examine the influence of domestic policy in place before spillovers take place.

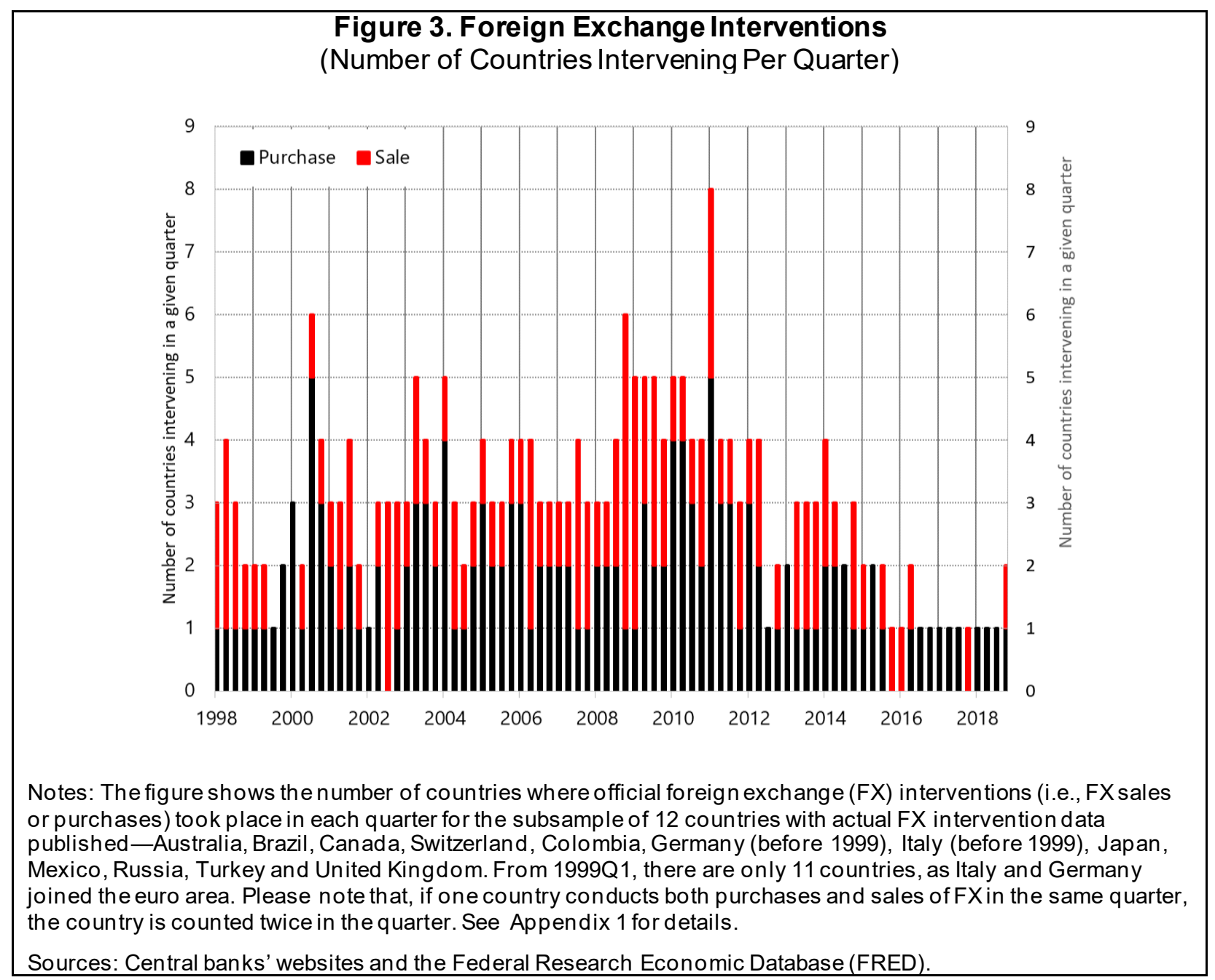

\footnotetext{
${ }^{20}$ Mano and Sgherri (2020) show that the use of FXI is heterogeneous even within emerging market economies. Please also see Chamon, et al. (2019) and Fratzscher, et al. (2019).
} 


\section{A. Mitigating the Impact of Spillovers on Leverage}

Starting with mitigation, we ask whether macroprudential, CFM and FXI policies can neutralize the influence of prolonged U.S. monetary policy easing on financial firm leverage. Policy is, however, endogenous. When they act, policymakers are reacting to changing macroeconomic and financial conditions. To address the possibility of reverse causality, we look at the impact of policy shocks - that is, we use the portion of the policy action that is orthogonal to changes in the macro-financial environment.

Specifically, we estimate the following equation:

$$
\ln \left(\mathrm{Y}_{\mathrm{ikt}}\right)=\alpha_{0}+\gamma_{1} P_{k, t}^{\text {Shock }}+\gamma_{2} P_{k, t}^{\text {Shock }} \mathrm{xD}_{\mathrm{t}}^{\mathrm{US}}+\beta \mathrm{X}_{\mathrm{kt}-1}+\mathrm{c}_{\mathrm{i}}+\mathrm{d}_{\mathrm{t}}+\varepsilon_{\mathrm{ikt}},
$$

where $\mathrm{Y}_{\mathrm{ikt}}$ is leverage of firm $i$ in country $k, \mathrm{D}_{\mathrm{t}}^{\mathrm{US}}$ is the U.S. easing duration defined above, $P_{k, t}^{\text {Shock }}$ is the policy shock, $\mathrm{X}_{\mathrm{kt}-1}$ is a vector of domestic controls listed in the previous section, $\mathrm{c}_{\mathrm{i}}$ is the firm fixed effects, $d_{t}$ is the time fixed effects to control for global factors (including $D_{t}^{U S}$ on its own), and $\varepsilon_{\mathrm{ikt}}$ is the residual. ${ }^{21}$ Our interest is in the direct impact of a shock $\left(\gamma_{1}\right)$, the marginal effect of reacting to U.S. policy easing $\left(\gamma_{2} D_{t}^{U S}\right)$, and the combined influence $\left(\gamma_{1}+\gamma_{2} D_{t}^{U S}\right)$.

Briefly, we construct the policy shocks as the deviations from estimated policy rules, following Brandao-Marques et al. (2020). For macroprudential policy and CFMs, we begin with a set of monthly indicators that take on a value of +1 for a tightening, -1 for a loosening, and 0 for neutral or no action, and aggregate them to create a quarterly series. Using an ordered probit, we estimate a policy reaction function, from which we derive a series of shocks. The units of the policy shock are thus the number of tightening actions, net of the number of loosening actions, within the specified policy category during a given quarter. For FXI, we construct the shock as the residual of an OLS regression of a policy reaction function, using the amount of FXI in percent of GDP. Appendix 1.B provides additional details.

Turning to the results, Tables 2 reports estimates of the marginal impact of a one standard deviation policy shock evaluated at the sample median. Both the standard deviation of the shocks and the median leverage for each group are noted in the table. So, for example, the standard deviation of the shocks to macroprudential policy is 0.53 for all instruments, 0.14 for borrowerbased instruments, and 0.47 for institution-based instruments. For CFMs, the standard deviation is 0.27. (Recall that these are all based on the number of policy-tightening actions, net of the number of loosening actions.) For FXI the standard deviation is 0.0018 .

\footnotetext{
${ }^{21}$ Time fixed effects are not included in equation (2) because they would absorb the effect of prolonged U.S. monetary policy easing, which is our primary variable of interest there. However, in equation (3), our primary interest is to see the impact of the use of policy on financial firms' leverage. We include time fixed effects here to control for global factors, which could be correlated with the use of policy measures.
} 
We group the results into five blocks, one for each group of policies that we study. These include the borrower- and institution-based macroprudential policy measures, as well as the sum; the capital inflow measures; and foreign exchange interventions. We highlight in yellow those estimates that are significantly different from zero at the 1 percent or 5 percent level. Estimates that are significantly different from zero at the 10 percent level are in gray. Since we hope for negative estimates - policy interventions intended to increase systemic financial resilience should be associated with reduced leverage — we indicate positive estimates in red.

\begin{tabular}{|c|c|c|c|c|c|c|c|}
\hline \multicolumn{8}{|c|}{ Table 2. Mitigation Policies } \\
\hline & & Banks & $\begin{array}{l}\text { Insurance } \\
\text { Companies }\end{array}$ & $\begin{array}{l}\text { Real Estate } \\
\text { Firms }\end{array}$ & $\begin{array}{c}\text { Asset } \\
\text { Managers }\end{array}$ & $\begin{array}{l}\text { Investment } \\
\text { Banks }\end{array}$ & Other \\
\hline \multicolumn{8}{|c|}{ A. Macroprudential Policy Shocks } \\
\hline \multirow{3}{*}{$\begin{array}{c}\text { All } \\
\text { measures } \\
\text { (s.d. }=0.53)\end{array}$} & $\begin{array}{c}\text { Macroprudential } \\
\text { tightening }\end{array}$ & $\begin{array}{l}-0.254 \dagger \\
(0.148)\end{array}$ & $\begin{array}{l}-0.037 \\
(0.077)\end{array}$ & $\begin{array}{c}0.007 \\
(0.015)\end{array}$ & $\begin{array}{l}0.011 \\
(0.01)\end{array}$ & $\begin{array}{l}-0.243 \\
(0.167)\end{array}$ & $\begin{array}{l}0.029 \\
(0.02)\end{array}$ \\
\hline & Interaction & $\begin{array}{l}-0.017 \\
(0.013)\end{array}$ & $\begin{array}{l}0.011 \\
(0.01)\end{array}$ & $\begin{array}{c}-0.003^{* *} \\
(0.001)\end{array}$ & $\begin{array}{c}-0.002^{* *} \\
(0.001)\end{array}$ & $\begin{array}{c}0.016 \\
(0.011)\end{array}$ & $\begin{array}{l}-0.004^{*} \\
(0.002)\end{array}$ \\
\hline & Total effect & $\begin{array}{l}-0.332^{* *} \\
(0.111)\end{array}$ & $\begin{array}{c}0.014 \\
(0.068)\end{array}$ & $\begin{array}{l}-0.008 \\
(0.013)\end{array}$ & $\begin{array}{c}0.002 \\
(0.008)\end{array}$ & $\begin{array}{l}-0.171 \\
(0.134)\end{array}$ & $\begin{array}{l}0.009 \\
0.009 \\
(0.020)\end{array}$ \\
\hline \multirow{3}{*}{$\begin{array}{c}\text { Borrower- } \\
\text { based } \\
\text { measures } \\
\text { (s.d.= 0.14) }\end{array}$} & $\begin{array}{l}\text { Macroprudential } \\
\text { tightening }\end{array}$ & $\begin{array}{l}-0.124^{*} \\
(0.054)\end{array}$ & $\begin{array}{l}-0.012 \\
(0.03)\end{array}$ & $\begin{array}{c}0.002 \\
(0.007)\end{array}$ & $\begin{array}{c}0.005 \\
(0.007)\end{array}$ & $\begin{array}{l}-0.073 \\
(0.069)\end{array}$ & $\begin{array}{c}0.017 \\
(0.014)\end{array}$ \\
\hline & Interaction & $\begin{array}{l}-0.001 \\
(0.005)\end{array}$ & $\begin{array}{l}0.010^{* *} \\
(0.002)\end{array}$ & $\begin{array}{c}-0.001^{* *} \\
(0)\end{array}$ & $\begin{array}{c}-0.001 \dagger \\
(0)\end{array}$ & $\begin{array}{l}0.009^{*} \\
(0.004)\end{array}$ & $\begin{array}{l}-0.002 \dagger \\
(0.001)\end{array}$ \\
\hline & Total effect & $\begin{array}{l}-0.129^{* *} \\
(0.050)\end{array}$ & $\begin{array}{c}0.034 \\
(0.030)\end{array}$ & $\begin{array}{l}-0.004 \\
(0.006)\end{array}$ & $\begin{array}{c}0.001 \\
(0.005)\end{array}$ & $\begin{array}{l}-0.033 \\
(0.055)\end{array}$ & $\begin{array}{c}0.008 \\
(0.013)\end{array}$ \\
\hline \multirow{3}{*}{$\begin{array}{c}\text { Institution- } \\
\text { based } \\
\text { measures } \\
\text { (s.d.= 0.47) }\end{array}$} & $\begin{array}{c}\text { Macroprudential } \\
\text { tightening }\end{array}$ & $\begin{array}{l}-0.327^{* \star} \\
(0.121)\end{array}$ & $\begin{array}{c}0.031 \\
(0.084)\end{array}$ & $\begin{array}{c}0.004 \\
(0.014)\end{array}$ & $\begin{array}{l}0.020 \dagger \\
(0.011)\end{array}$ & $\begin{array}{l}-0.245 \dagger \\
(0.151)\end{array}$ & $\begin{array}{l}0.029 \\
(0.02)\end{array}$ \\
\hline & Interaction & $\begin{array}{l}-0.011 \\
(0.016)\end{array}$ & $\begin{array}{l}-0.010 \\
(0.01)\end{array}$ & $\begin{array}{l}-0.002^{* *} \\
(0.001)\end{array}$ & $\begin{array}{l}-0.002^{*} \\
(0.001)\end{array}$ & $\begin{array}{c}0.007 \\
(0.011)\end{array}$ & $\begin{array}{c}0.000 \\
(0.002)\end{array}$ \\
\hline & Total effect & $\begin{array}{c}-0.378^{* *} \\
(0.100)\end{array}$ & $\begin{array}{c}-0.014 \\
(0.073) \\
\end{array}$ & $\begin{array}{l}-0.006 \\
(0.014) \\
\end{array}$ & $\begin{array}{c}0.011 \\
(0.009)\end{array}$ & $\begin{array}{c}-0.214 \dagger \\
(0.119)\end{array}$ & $\begin{array}{c}0.030 \\
(0.020) \\
\end{array}$ \\
\hline \multicolumn{8}{|c|}{ B. Capital Inflow Policy Shocks } \\
\hline \multirow{3}{*}{$\begin{array}{c}\text { Inflow } \\
\text { CFMs } \\
\text { (s.d. }=0.27 \text { ) }\end{array}$} & CFM tightening & $\begin{array}{l}-0.097 \\
(0.095) \\
\end{array}$ & $\begin{array}{c}-0.041 \\
(0.039) \\
\end{array}$ & $\begin{array}{l}-0.003 \\
(0.009) \\
\end{array}$ & $\begin{array}{c}0.002 \\
(0.004) \\
\end{array}$ & $\begin{array}{l}-0.142^{*} \\
(0.061) \\
\end{array}$ & $\begin{array}{l}-0.008 \\
(0.016) \\
\end{array}$ \\
\hline & Interaction & $\begin{array}{l}0.006 \\
(0.006)\end{array}$ & $\begin{array}{l}0.003 \\
(0.007)\end{array}$ & $\begin{array}{l}0.000 \\
(0.001)\end{array}$ & $\begin{array}{l}0.001 \dagger \\
(0.001)\end{array}$ & $\begin{array}{l}0.018^{* *} \\
(0.006)\end{array}$ & $\begin{array}{c}0.002 \\
(0.001)\end{array}$ \\
\hline & Total effect & $\begin{array}{l}-0.067 \\
(0.071)\end{array}$ & $\begin{array}{l}-0.029 \\
(0.039)\end{array}$ & $\begin{array}{l}-0.003 \\
(0.006)\end{array}$ & $\begin{array}{l}-0.003 \\
(0.004) \\
\end{array}$ & $\begin{array}{l}-0.058 \\
(0.049) \\
\end{array}$ & $\begin{array}{c}0.002 \\
(0.012) \\
\end{array}$ \\
\hline $\begin{array}{l}\text { Median } \\
\text { Leverage }\end{array}$ & & 14.4 & 8.7 & 1.9 & 1.2 & 6.3 & 2.5 \\
\hline
\end{tabular}




\begin{tabular}{|c|c|c|c|c|c|c|c|}
\hline \multicolumn{8}{|c|}{ Table 2. Mitigation Policies (Concluded) } \\
\hline & & Banks & $\begin{array}{l}\text { Insurance } \\
\text { Companies }\end{array}$ & $\begin{array}{c}\text { Real } \\
\text { Estate } \\
\text { Firms }\end{array}$ & $\begin{array}{c}\text { Asset } \\
\text { Managers }\end{array}$ & $\begin{array}{l}\text { Investment } \\
\text { Banks }\end{array}$ & Other \\
\hline \multicolumn{8}{|c|}{ C. Foreign Exchange Intervention } \\
\hline \multirow{3}{*}{$\begin{array}{c}\text { FXI } \\
\text { (s.d. = } \\
0.0018)\end{array}$} & $\begin{array}{c}\mathrm{FX} \\
\text { purchase }\end{array}$ & $\begin{array}{l}-0.031 \\
(0.023)\end{array}$ & $\begin{array}{l}-0.005 \\
(0.017)\end{array}$ & $\begin{array}{c}-0.003 \\
(0.002)\end{array}$ & $\begin{array}{l}-0.001 \\
(0.002)\end{array}$ & $\begin{array}{l}-0.012 \\
(0.018)\end{array}$ & $\begin{array}{l}-0.007^{*} \\
(0.004)\end{array}$ \\
\hline & Interaction & $\begin{array}{c}0.001 \\
(0.002) \\
\end{array}$ & $\begin{array}{c}0.001 \\
(0.001) \\
\end{array}$ & $\begin{array}{c}0.0000 \\
(0.0002) \\
\end{array}$ & $\begin{array}{c}-0.0001 \\
(0.0001) \\
\end{array}$ & $\begin{array}{c}0.001 \\
(0.001) \\
\end{array}$ & $\begin{array}{c}0.0003 \\
(0.0003) \\
\end{array}$ \\
\hline & Total effect & $\begin{array}{l}-0.027 \\
(0.019) \\
\end{array}$ & $\begin{array}{l}-0.003 \\
(0.013) \\
\end{array}$ & $\begin{array}{l}-0.002 \\
(0.002) \\
\end{array}$ & $\begin{array}{l}-0.001 \\
(0.001) \\
\end{array}$ & $\begin{array}{l}-0.009 \\
(0.013) \\
\end{array}$ & $\begin{array}{l}-0.006^{*} \\
(0.003) \\
\end{array}$ \\
\hline $\begin{array}{c}\text { Median } \\
\text { Leverage }\end{array}$ & & 14.4 & 8.7 & 1.9 & 1.2 & 6.3 & 2.5 \\
\hline \multicolumn{8}{|c|}{$\begin{array}{l}\text { Sources: Bloomberg, Datastream, Haver, WEO, Worldscope, others (see Appendix 1), and authors' estimates. } \\
\text { Notes: Based on equation (3), reported estimates are for the marginal impact of one standard deviation policy } \\
\text { shock on leverage, evaluated at the sample mean for U.S monetary policy duration (4.6 quarters) and the median } \\
\text { for leverage. One standard deviation policy shock is shown in parenthesis in the first column, and it is calculated by } \\
\text { taking country-specificstandard deviations and then taking their median. Standard errors of the estimated } \\
\text { coefficients, in parentheses, use the method of Driscoll and Kraay (1998) and are robust to heteroscedasticity and } \\
\text { cross-sectional and temporal dependences with stationary variables. For macroprudential policy shocks, data are } \\
\text { from 1998 Q1 to } 2018 \text { Q4. For capital inflow policy shocks, the sample is from } 1998 \text { Q3 to } 2017 \text { Q4 and for FXI } \\
\text { from 1998 Q3 to } 2018 \text { Q4. }\end{array}$} \\
\hline
\end{tabular}

As in Table 1, the numbers in Table 2 are in the same units as the leverage variable. This means that a one standard deviation shock to all macroprudential measures - an unexpected increase of 0.53 in the number of tightening actions - results in decline in bank leverage from the median of 14.441 to 14.187 , a decrease of 0.254 (the number in the top-left-most cell in the table).

Overall, the results are discouraging. While the macroprudential policy does have an impact on banks - note the yellow highlighted cells in the first row of the top three panels - the interaction term tends to be both statistically and economically small. Even in the cases where estimates are statistically significantly negative - that is the case for real estate firms, asset managers, and other financial firms - the impact is never greater than 0.004 . While macroprudential policy may succeed in reducing bank leverage in normal times, it is generally ineffective at containing the leverage spillovers arising from prolonged U.S. monetary policy easing. ${ }^{22}$

Other studies also find weak effects when macroprudential tightening is in reaction to easy financial conditions. Brandao-Marques et al. (2020) conclude that tightening macroprudential policy in response to a loosening shock in financial conditions does not offset its stimulating effects on output in the short term. And Gelos et al. (2019) find that macroprudential actions in

\footnotetext{
${ }^{22}$ Our result of significant effects on bank leverage in normal times ("Total effect" in Section A of Table 2 for "Banks") is consistent with the findings in Claessens et al. (2013), Zhang and Zoli (2016), and Forbes et al. (2015). The insignificant effects on non-bank financial institutions' leverage could reflect the fact that macroprudential policies have been mostly applied to loans by banks (Cizel et al. 2019).
} 
response to an adverse shock in global financial conditions do not affect the short-term outlook for portfolio inflows. However, both studies report some benefits in the medium term, providing mild support for the pre-emptive use of macroprudential policies that we examine below.

For CFMs, the effects tend to be even smaller and less statistically significant than those for macroprudential policy (Section B of Table 2). That is, the reactive tightening of CFMs appear to be ineffective. We note that our "all inflow" restriction index may include some less relevant restrictions, thereby obscuring the impact of the effective measures. ${ }^{23}$ With this qualification, we conclude that there is weak evidence for the effectiveness of reactive tightening of CFMs.

Reactive FXI that aims to counteract the spillover of U.S. policy on financial institution leverage is not promising, either. Our estimates of the interaction term $\left(\gamma_{2}\right)$ in Section C of Table 2 are close to zero for all industries. Although the results for the total effect of FXI is negative in all industries, it tends to be small and statistically insignificant. That is, official FX purchases aimed at countering capital inflows during a prolonged U.S. monetary policy easing may discourage some risk-taking of financial firms, but their overall impact seems to be minor. Since firms' response to FXI could depend on its FX exposure, we also consider alternative specification, adding the firm-level stock of U.S. dollar liabilities in the regression. ${ }^{24}$ But we find that the results are broadly the same as those reported in Table 2: even accounting for variation in U.S. dollar exposure, the effects of the reactive FXI on financial institution leverage are almost zero.

These results are again consistent with the few studies that are available. Examining the reactive use of CFMs and FXI in response to global shocks, others also report limited evid ence for their effectiveness. For example, Brandao-Marques et al. (2020) find that tightening CFMs or purchasing FX to counter loose global financial conditions entail very small benefits on macroeconomic stability. Gelos et al. (2019) conclude that, in response to an adverse shock, tightening CFMs exacerbates the downside risks to portfolio outflows, so it is counterproductive. They find that FX sales in the face of adverse shocks reduce the tail risk of large outflows but only in the short term.

\footnotetext{
${ }^{23}$ To address this, we ideally want to consider a CMF shock based on the restrictions that target inflows of debt, money markets and financial credits, which are arguably more relevant for financial firms' leverage. However, since these sub-categories are only available from 2016 in the IMF's AREAER database, we cannot conduct robustness checks in a reliable way.

${ }^{24}$ Using EIKON's issuance-level data of new bonds and syndicated loans by currency, we constructed the time-series of the USD liability stock as a share of the total stock of each firm. Our underlying assumptions are (1) the USD liability share in the category of bonds and syndicated loans is the same for other liability categories; and (2) the debt is paid entirely at the maturity (due to the lack of repayment data). See also Appendix 1.
} 


\section{B. Preventing the Impact of Spillovers on Leverage}

Turning to prevention, we examine whether pre-existing policy measures can inoculate a country's financial system from the potentially damaging spillovers arising from U.S. monetary easing. Our goal is to see if pre-existing policy can build resilience to adverse events, including U.S. monetary policy easing. To address this question, we substitute the lagged indicator of the policies into equation (3) and estimate:

$$
\ln \left(\mathrm{Y}_{\mathrm{ikt}}\right)=\alpha_{0}+\gamma_{1} P_{k, t-4}+\gamma_{2} P_{k, t-4} \times \mathrm{D}_{\mathrm{t}}^{\mathrm{US}}+\beta \mathrm{X}_{\mathrm{kt}-1}+\mathrm{c}_{\mathrm{i}}+\mathrm{d}_{\mathrm{t}}+\varepsilon_{\mathrm{ikt}},
$$

where $P_{k, t-4}$ is the four-quarter lag of the measure of existing policy in country $\mathrm{k}$. All other variables are as in equation (3).

As the measure of existing policy $\left(P_{k, t-4}\right)$, we use the four-quarter lag of the number of policy instruments in place as a share of total number of policy instruments under consideration. This is a number from 0 to 100 , with the higher values indicating that more instruments are in use. For macroprudential measures (all, borrower-based, financial-institution-based), we use the annual indicators by Cerutti et al.'s (2017), covering from 2000 to $2017 .{ }^{25}$ For CFMs, we use the quarterly indices from Baba et al. (forthcoming). For FX buffers, on the other hand, we use the four-quarter lag of FX reserves as a percentage of GDP. Arguably, pre-existing policies are less correlated with current macro-financial developments, and thus less subject to reverse causality. For this reason, we estimate (4) using the actual policies themselves rather than policy shocks.

We note that because they reflect introductions and repeals of a regulation only (ignoring any changes in intensity), these existence-based indicators have limited variation. For example, for borrower-based macroprudential measures, there is no variation in 16 of 28 countries, while all but two countries have variation for institution-based measures. ${ }^{26}$ For the capital inflow measures, there are three countries for which the data show no variation over the sample: Belgium, Ireland and the Netherlands. ${ }^{27}$

Our results strongly suggest that preventive policy works. In Table 3, we report our estimates of equation (4) for six sectors and five types of policy interventions. First, 35 of the 90 estimated coefficients are significantly less than zero at the 5 percent level or lower (these are the negative numbers highlighted in yellow). Furthermore, some of the effects are quite large.

\footnotetext{
${ }^{25}$ Please note that the indicator by Cerutti et al. (2017) is only available at the annual frequency and covering less instrumen ts than those from the IMF's iMaPP database that we used for the mitigation analysis.

${ }^{26}$ For borrower-based macroprudential measures, over the 2000 to 2017 sample, there is no variation in the measure of existing policy $\left(P_{k, t}\right)$ for Australia, Austria, Belgium, Colombia, France, Germany, Hong Kong, Japan, Mexico, Malay sia, Portugal, Russia, Spain, Switzerland, South Africa and the United Kingdom. In the case of the institution-based measures, Brazil and Malaysia have no variation.

${ }^{27}$ Such limited or missing variation in these policies -in-place indices could cause the attenuation bias in the estimated policy effects. See Erten et al. (2020).
} 


\begin{tabular}{|c|c|c|c|c|c|c|c|}
\hline \multicolumn{8}{|c|}{ Table 3. Prevention Policies } \\
\hline & & Banks & $\begin{array}{l}\text { Insurance } \\
\text { Companies }\end{array}$ & $\begin{array}{c}\text { Real } \\
\text { Estate } \\
\text { Firms } \\
\end{array}$ & $\begin{array}{c}\text { Asset } \\
\text { Managers }\end{array}$ & $\begin{array}{l}\text { Investment } \\
\text { Banks }\end{array}$ & Other \\
\hline \multicolumn{8}{|c|}{ A. Macroprudential Policy } \\
\hline \multirow{3}{*}{$\begin{array}{c}\text { All } \\
\text { measures } \\
(\Delta=8.3 \%)\end{array}$} & $\begin{array}{c}\text { Macroprudential } \\
\text { tightening }\end{array}$ & $\begin{array}{c}-0.798^{* *} \\
(0.187) \\
\end{array}$ & $\begin{array}{l}-0.454^{*} \\
(0.209) \\
\end{array}$ & $\begin{array}{l}-0.015 \\
(0.017) \\
\end{array}$ & $\begin{array}{l}0.043^{* *} \\
(0.016) \\
\end{array}$ & $\begin{array}{c}0.151 \\
(0.236) \\
\end{array}$ & $\begin{array}{l}0.027 \\
(0.046) \\
\end{array}$ \\
\hline & Interaction & $\begin{array}{c}-0.042^{* *} \\
(0.013) \\
\end{array}$ & $\begin{array}{c}0.003 \\
(0.009) \\
\end{array}$ & $\begin{array}{l}-0.006^{* *} \\
(0.002)\end{array}$ & $\begin{array}{l}-0.003^{*} \\
(0.001)\end{array}$ & $\begin{array}{l}-0.025^{*} \\
(0.012)\end{array}$ & $\begin{array}{r}-0.010 \dagger \\
(0.006) \\
\end{array}$ \\
\hline & Total effect & $\begin{array}{l}-0.993^{* *} \\
(0.191) \\
\end{array}$ & $\begin{array}{l}-0.441^{*} \\
(0.178) \\
\end{array}$ & $\begin{array}{c}-0.043^{* *} \\
(0.016) \\
\end{array}$ & $\begin{array}{l}0.030^{*} \\
(0.014)\end{array}$ & $\begin{array}{c}0.034 \\
(0.202) \\
\end{array}$ & $\begin{array}{l}-0.021 \\
(0.042) \\
\end{array}$ \\
\hline \multirow{3}{*}{$\begin{array}{c}\text { Borrower- } \\
\text { based } \\
\text { measures } \\
(\Delta=50 \%)\end{array}$} & $\begin{array}{c}\text { Macroprudential } \\
\text { tightening }\end{array}$ & $\begin{array}{c}-1.958^{* *} \\
(0.31) \\
\end{array}$ & $\begin{array}{l}0.979^{* *} \\
(0.339) \\
\end{array}$ & $\begin{array}{c}0.052 \\
(0.056) \\
\end{array}$ & $\begin{array}{c}0.005 \\
(0.024) \\
\end{array}$ & $\begin{array}{l}1.159^{* *} \\
(0.391) \\
\end{array}$ & $\begin{array}{l}0.238 \dagger \\
(0.122)\end{array}$ \\
\hline & Interaction & $\begin{array}{l}-0.104^{* *} \\
(0.031)\end{array}$ & $\begin{array}{l}-0.043^{*} \\
(0.021) \\
\end{array}$ & $\begin{array}{c}-0.009^{* *} \\
(0.003)\end{array}$ & $\begin{array}{l}-0.002 \dagger \\
(0.001) \\
\end{array}$ & $\begin{array}{l}-0.061^{* *} \\
(0.017)\end{array}$ & $\begin{array}{l}-0.022^{*} \\
(0.009)\end{array}$ \\
\hline & Total effect & $\begin{array}{c}-2.441^{* *} \\
(0.242) \\
\end{array}$ & $\begin{array}{l}0.779^{* *} \\
(0.288) \\
\end{array}$ & $\begin{array}{c}0.012 \\
(0.050) \\
\end{array}$ & $\begin{array}{l}-0.006 \\
(0.022) \\
\end{array}$ & $\begin{array}{l}0.876^{*} \\
(0.347) \\
\end{array}$ & $\begin{array}{c}0.134 \\
(0.106) \\
\end{array}$ \\
\hline \multirow{3}{*}{$\begin{array}{c}\text { Institution } \\
\text {-based } \\
\text { measures } \\
(\Delta=10 \%)\end{array}$} & $\begin{array}{c}\text { Macroprudential } \\
\text { tightening }\end{array}$ & $\begin{array}{l}-0.124 \\
(0.197) \\
\end{array}$ & $\begin{array}{l}-0.983^{* *} \\
(0.157) \\
\end{array}$ & $\begin{array}{l}-0.047 \dagger \\
(0.025) \\
\end{array}$ & $\begin{array}{l}0.056^{*} \\
(0.023) \\
\end{array}$ & $\begin{array}{l}-0.297 \dagger \\
(0.173) \\
\end{array}$ & $\begin{array}{l}-0.067 \\
(0.069) \\
\end{array}$ \\
\hline & Interaction & $\begin{array}{c}-0.034^{* *} \\
(0.012) \\
\end{array}$ & $\begin{array}{c}0.017^{*} \\
(0.007) \\
\end{array}$ & $\begin{array}{c}-0.005^{* *} \\
(0.002)\end{array}$ & $\begin{array}{l}-0.004^{*} \\
(0.002) \\
\end{array}$ & $\begin{array}{l}0.004 \\
(0.01) \\
\end{array}$ & $\begin{array}{l}-0.006 \\
(0.006) \\
\end{array}$ \\
\hline & Total effect & $\begin{array}{c}-0.282 \\
(0.204) \\
\end{array}$ & $\begin{array}{c}-0.905^{\star *} \\
(0.146) \\
\end{array}$ & $\begin{array}{c}-0.071^{* *} \\
(0.025) \\
\end{array}$ & $\begin{array}{l}0.038 \dagger \\
(0.022) \\
\end{array}$ & $\begin{array}{c}-0.276 \dagger \\
(0.164) \\
\end{array}$ & $\begin{array}{l}-0.093 \\
(0.069) \\
\end{array}$ \\
\hline \multicolumn{8}{|c|}{ B. Capital Inflow Policy } \\
\hline \multirow{3}{*}{$\begin{array}{c}\text { Inflow } \\
\text { CFMs } \\
(\Delta=3.45)\end{array}$} & CFM tightening & $\begin{array}{c}0.238 \\
(0.145)\end{array}$ & $\begin{array}{l}0.290^{*} \\
(0.139)\end{array}$ & $\begin{array}{l}0.059^{* *} \\
(0.014)\end{array}$ & $\begin{array}{l}-0.010 \\
(0.011)\end{array}$ & $\begin{array}{c}-0.337^{* *} \\
(0.113)\end{array}$ & $\begin{array}{l}0.242^{* *} \\
(0.047)\end{array}$ \\
\hline & Interaction & $\begin{array}{c}-0.026^{* *} \\
(0.007)\end{array}$ & $\begin{array}{c}-0.016^{* *} \\
(0.004)\end{array}$ & $\begin{array}{l}-0.002^{* *} \\
(0.0005)\end{array}$ & $\begin{array}{c}-0.0004 \\
(0.0005)\end{array}$ & $\begin{array}{c}0.005 \\
(0.008) \\
\end{array}$ & $\begin{array}{l}-0.003^{*} \\
(0.001) \\
\end{array}$ \\
\hline & Total effect & $\begin{array}{c}0.119 \\
(0.136) \\
\end{array}$ & $\begin{array}{l}0.215 \dagger \\
(0.130)\end{array}$ & $\begin{array}{l}0.051^{* *} \\
(0.014)\end{array}$ & $\begin{array}{l}-0.012 \\
(0.010) \\
\end{array}$ & $\begin{array}{c}-0.313^{* *} \\
(0.099)\end{array}$ & $\begin{array}{l}0.230^{* *} \\
(0.048)\end{array}$ \\
\hline $\begin{array}{c}\text { Median } \\
\text { Leverage }\end{array}$ & & 14.4 & 8.7 & 1.9 & 1.2 & 6.3 & 2.5 \\
\hline
\end{tabular}




\begin{tabular}{|c|c|c|c|c|c|c|c|}
\hline \multicolumn{8}{|c|}{ Table 3. Prevention Policies (cont.) } \\
\hline & & Banks & $\begin{array}{l}\text { Insurance } \\
\text { Companies }\end{array}$ & $\begin{array}{c}\text { Real } \\
\text { Estate } \\
\text { Firms }\end{array}$ & $\begin{array}{c}\text { Asset } \\
\text { Managers }\end{array}$ & $\begin{array}{l}\text { Investment } \\
\text { Banks }\end{array}$ & Other \\
\hline \multicolumn{8}{|c|}{ C. Foreign Exchange Buffers } \\
\hline \multirow{3}{*}{$\begin{array}{c}\text { FX buffers } \\
(\Delta=9.78)\end{array}$} & $\begin{array}{l}\text { FX buffer } \\
\text { increase }\end{array}$ & $\begin{array}{l}-0.020 \\
(0.04) \\
\end{array}$ & $\begin{array}{c}-0.098^{* *} \\
(0.017) \\
\end{array}$ & $\begin{array}{c}0.003 \\
(0.005) \\
\end{array}$ & $\begin{array}{l}0.007^{* *} \\
(0.002) \\
\end{array}$ & $\begin{array}{c}-0.145^{\star *} \\
(0.014) \\
\end{array}$ & $\begin{array}{l}-0.017 \\
(0.012) \\
\end{array}$ \\
\hline & Interaction & $\begin{array}{c}-0.006^{* *} \\
(0.002) \\
\end{array}$ & $\begin{array}{l}-0.002 \\
(0.001) \\
\end{array}$ & $\begin{array}{l}-0.0003^{*} \\
(0.0001) \\
\end{array}$ & $\begin{array}{l}0.0001^{*} \\
(0.0001) \\
\end{array}$ & $\begin{array}{r}-0.0003 \\
(0.001) \\
\end{array}$ & $\begin{array}{l}-0.001^{* *} \\
(0.0002) \\
\end{array}$ \\
\hline & Total effect & $\begin{array}{l}-0.049 \\
(0.041) \\
\end{array}$ & $\begin{array}{c}-0.107^{* *} \\
(0.018) \\
\end{array}$ & $\begin{array}{c}0.002 \\
(0.005) \\
\end{array}$ & $\begin{array}{l}0.008^{* *} \\
(0.002) \\
\end{array}$ & $\begin{array}{c}-0.146^{* *} \\
(0.015) \\
\end{array}$ & $\begin{array}{l}-0.020 \\
(0.012) \\
\end{array}$ \\
\hline $\begin{array}{c}\text { Median } \\
\text { Leverage }\end{array}$ & & 14.4 & 8.7 & 1.9 & 1.2 & 6.3 & 2.5 \\
\hline \multicolumn{8}{|c|}{$\begin{array}{l}\text { Sources: Bloomberg, Datastream, Haver, WEO, Worldscope, others (see Appendix 1), and authors' estimates. } \\
\text { Notes: Based on equation (4), reported estimates are for the marginal impact of the change in the preventive policy } \\
\text { indicator on leverage, evaluated at the sample mean for U.S monetary policy duration (4.6 quarters) and the median } \\
\text { for leverage. The change of each preventive policy indicator is shown in parenthes es in the first column, and it } \\
\text { corresponds to the activation of one additional instrument for macroprudential policies and CFMs. For FX buffers, it is } \\
\text { calculated by taking country-specific standard deviations and then taking their median. Standard errors of the } \\
\text { estimated coefficients, in parentheses, use the method of Driscoll and Kraay (1998) and are robust to } \\
\text { heteroscedasticity and cross-sectional and temporal dependences with stationary variables. For macroprudential } \\
\text { policy, data are from 1998 Q1 to } 2018 \text { Q4. For capital inflow policy shocks, the sample is from } 1998 \text { Q3 to } 2017 \text { Q4 } \\
\text { and for FXI from } 1998 \text { Q3 to } 2018 \text { Q4. }\end{array}$} \\
\hline
\end{tabular}

In a number of cases, those that in red, policy do seem to be counterproductive. In our view, these are likely a consequence of the limited variation in the policy indices we employ. For example, in the case of impact of borrower-based macroprudential measures on insurance companies, the estimates are quite large and statistically significantly greater than zero at the 5 percent level. They are based on a very limited number of firm-quarter observations with policy variation (due to the lack of variation in 16 of 28 countries for borrower-based measures, as discussed earlier).

Looking at the details, the first column of the table shows that macroprudential policies are particularly effective at containing leverage buildup in banks. This is true for borrower-based measures, where the estimated coefficient is significant at the 1 percent level. For institution based measures, the impact is of the right sign, albeit imprecisely estimated. As we note earlier, this is unsurprising given that the bulk of these policies are currently aimed at banks.

Next, focusing on the top panel labelled "all measures", we see that the interaction $\left(\gamma_{2}\right)$ is significantly negative at the 5 percent level for banks, real estate firms, asset managers and investment banks. That is, a higher share of existing measures of macroprudential policy helps prevent the leverage spillovers from U.S. policy. The results using the two types of measures separately (in the corresponding estimates in the second and third panel) confirm this conclusion. There is a stark difference from the results in Table 2 - the mitigative effects $\left(\gamma_{2}\right)$ from the reactive tightening of macroprudential policy in response to prolonged U.S. monetary easing were generally not statistically significant. 
Turning to the overall impact of the pre-existing macroprudential policies, the term $\left(\gamma_{1}+\gamma_{2} \mathrm{D}_{\mathrm{t}}^{\mathrm{US}}\right)$ measures the percentage change in financial firms' leverage due to an increase in the share of already-in-use measures shown in the left-hand side panel. For example, for all measures, the experiment is an increase of 8.3 percent, which represents activation of one instrument. In all cases, we set the number of quarters of U.S. monetary easing to the sample average of 4.6. Our estimates suggest that the borrower-based measures have the intended impact on banks; and that institution-based measures succeed in depressing leverage in insurance companies and real estate firms. ${ }^{28}$

The results for preventive inflow CFMs are in section B of Table 3. They, too, imply that policy is effective in protecting the system against the buildup of leverage when there is prolonged U.S. monetary policy easing. Focusing on the interaction terms, we note that $\left(\gamma_{2}\right)$ is negative and significantly different from zero at the 5 percent level or greater in four of the six cases. ${ }^{29,} 30 \mathrm{We}$ note that the base effect $\left(\gamma_{1}\right)$ is positive in three cases (insurance companies, real estate firms and "other"). This perverse effect of CFMs in normal times could be a consequence of the protection that they offer for domestic financial firms - they may be able to take advantage of less volatile capital flows thanks to inflow restrictions.

Section $C$ reports estimates for the resilience afforded by additional FX buffers. While quantitatively small, we find evidence of FX buffers reducing the impact of U.S policy easing on leverage. This supports findings in the literature that official foreign reserve assets reduce vulnerabilities from external indebtedness. ${ }^{31}$

Results are robust to using a longer lag ( 8 quarters instead of 4 quarters used in the baseline) of policy instruments in place. Our conclusions on the efficacy of macroprudential and capital flow management policies in preventing the buildup of financial institution leverage in the face of monetary policy spillovers are consistent with those in other studies. For example, Klein (2012) and several other studies provide empirical evidence suggesting that macroprudential policies or CFMs reduce financial vulnerabilities. ${ }^{32}$

\footnotetext{
${ }^{28}$ The results for macroprudential are robust to using following alternative measures of pre-existing policy: the cumulative sum of the net number of tightening actions (i) in the past 4 quarters; (ii) in the past 8 qtrs; and (iii) since the start of the sample period. We constructed these alternative measures using the policy action indicators by Alam et al. (2019).

${ }^{29}$ The results are largely robust to the use of following alternative measures of pre-existing CFM restrictions: (i) A customized inflow restriction on three as set classes (debt, money market, financial credits) using Fernández et al. (2016) index; (ii) A customized restriction on all flows (both inflows and outflows) on the three asset categories using FARI and Fernández index, and (iii) Inflow restrictions on all asset classes using FARI and Fernández index.

${ }^{30}$ An important result of the work of Adrian et al. (2020) and Basu et al. (2020) is that restrictions on liabilities creating inflows (and not all inflows) may be desired to reduce vulnerabilities in small open economies. Our results on the effectiveness of p reexisting CFMs are robust to considering controls only on debt, money market and financial sector in flows.

${ }^{31}$ See Frankel and Saravelos (2012), Arce et al. (2019), Davis et al. (2020), Cubeddu et al. (2021), and Kalemli-Özcan (2021). Tong and Wei (2019), however, find that higher official reserves can also reduce book leverage of non-financial firms by reducing uncertainties.

${ }^{32}$ See Ostry et al. (2012), Bergant et al. (2020), Nier et al. (2020), Bhargava et al. (forthcoming), and Bouis et al. (forthcoming).
} 


\section{Conclusion}

In this paper, we start with confirming that the prolonged easing of U.S. monetary policy can contribute to the building up of leverage of financial firms in emerging markets and advanced economies. Faced with capital inflows and easy financial conditions, financial firms tend to increase their borrowing during good times. When the tide turns and capital inflows dry up, highly leveraged financial intermediaries may face currency depreciation and weakening balance sheets. With the potential to cascade, this can adversely affect the liquidity and solvency of firms, potentially increasing the fragility of the financial system. Depending on domestic characteristics and the nature of shocks, several non-U.S. authorities have deployed macroprudential tools, imposed capital controls, or engaged in foreign exchange interventions to enhance monetary autonomy and safeguard financial stability.

Our work is part of a growing body of research examining the implications of systematically deploying the three forms of policies to address financial fragility arising from external policy actions. Evidence to date indicates that these tools help in mitigating risks arising from excessive or unusually rapid increases in financial firms' leverage. In particular, in this study, we conclude that preventative policies - pre-emptively accumulating large external reserves or preserving preexisting capital control and macroprudential measures - are more effective in limiting the buildup of leverage in financial firms than reactive ones (those that are imposed in response to the spillovers).

In comparing the efficacy across these tools, we find that reactive macroprudential policies are either completely ineffective (banks, insurance companies, and investment banks) or have a very small impact (real estate firms, asset managers, and "other"). In contrast, when used pre emptively, our estimates of the impact of macroprudential policy mea sures are relatively large with the right sign across all financial firms (with the exception of insurance companies) and are particularly effective at containing leverage buildup in banks, where most measures are imposed. Looking at CFMs, reactive tightening has virtually no impact across all types of financial firms. In fact, we find that the effects tend to be even smaller and less statistically significant than those for macroprudential policy. On the other hand, pre-existing CFMs do seem to work in most cases (exceptions are asset managers and investment banks). Lastly, in the case of FXI, we find that reactive measures are broadly ineffective in countering U.S. monetary policy spillovers. But, if substantial FX reserves are built up prior to the capital inflow surge, they do help in reducing leverage, ceteris paribus, in three types of firms (banks, real estate firms, and “other').

Proactive use of any of these tools - macroprudential, CFM or FXI — does raise questions from a broader international and macroeconomic perspective. First, employing CFMs or tight macroprudential measures for a sustained period could undermine domestic financial market development, reduce the efficiency of capital allocation, lowering investment and putting a drag on economic growth. In other words, there may be a need to consider inter-temporal trade-offs between short-term financial resilience and long-term welfare. Second, if some countries actively preserve or use such tools, but others do not, this could shift U.S. monetary policy spillovers, 
further elevating system-wide financial risks in some places. That is, there may be multilateral aspects or negative spillovers amongst non-U.S. countries that would be worth exploring. And finally, we know very little about the longer-term distributional impact of using any of these tools. A better understanding of these can shed light on how policymakers can meet their myriad of objectives in the face of large and rising inequality and populism in their countries. These, and numerous additional important questions, are beyond the scope of this paper but seem vital to investigate if we are to fully understand how to ensure financial stability and meet longer term welfare goals, especially in emerging market countries. These findings can be cast within the IMF's Integrated Policy Framework, which advocates to complement monetary policy with FXI, CFM, and macroprudential tools to manage the impact of external financial conditions on macroeconomic performance and domestic financial stability. 


\section{APPENDIX 1. DATA SOURCES AND DEFINITIONS}

\section{A. Panel Data of Financial Firms}

We conduct our analysis using a panel data set of 950 publicly listed financial firms in 28 non-US countries (Table A1) from 1998 Q1 to 2018 Q4. We source firm-level financial data from the Worldscope (Thomson Reuters), which harmonizes the accounting presentations and definitions, allowing for cross-country analysis. Based on MSCI's Global Industry Classification Standard, we classify financial firms into six industry groups: banks, insurance companies, investment banks, asset managers, and other financials. To accurately capture market valuation of firms' assets and equity, we restrict our sample to firms whose securities are actively traded. To assess this, we require that they be constituents of the Bloomberg BWORLD Index since the start of its sample. ${ }^{33}$ Table A2 shows the number of firms in each sector and country.

Table A3 explains the definitions of key variables and their sources. Table A4 provides the list of the main stock indicators. Figure A1 shows the time series of leverage measured by the asset-toequity ratio, which is our key indicator of firms' vulnerabilities, by industry.

\section{B. Policy Variables}

We use different types of variables for mitigative and preventive policy actions. For mitigative policy actions (Section 3.A.), following Brandao-Marques et al. (2020), we construct "policy shocks" by estimating policy reaction functions for each policy. The estimation method differs across policies, because types of the available data are different. For macroprudential policy and CFMs, we estimate ordered probit models, using the dummy-type indicators of policy easing and tightening actions. For FXIs, we use OLS regressions because FXI data are continuous. Table A5 provides the details.

For preventive policy actions (Section 3.B.), we construct the indicators of pre-existing policy. For macroprudential policy and CFMs, using the existence-based indicators, we construct the share of policy instruments in place and use its four-quarter lag as the indicator of pre-existing policy. For FXIs, we use the four-quarter-lag of official international reserves excluding gold in percentage of GDP. Table A6 provides the details. Table A7 provides the summary statistics.

\footnotetext{
${ }^{33}$ We thank Martin Saldias, who kindly shared the idea to construct the "active firms" list.
} 


\begin{tabular}{|c|c|}
\hline \multicolumn{2}{|c|}{ Table A1. Sample Economies } \\
\hline Advanced Economies & Emerging Market and Developing Economies \\
\hline $\begin{array}{l}20 \text { economies: Austria (AUT), Australia (AUS), } \\
\text { Belgium (BEL), Canada (CAN), Finland (FIN), } \\
\text { France (FRA), Germany (DEU), Hong Kong SAR } \\
\text { (HKG), Ireland (IRL), Israel (ISR), Italy (ITA), } \\
\text { Japan (JPN), Netherlands (NLD), Portugal (PRT), } \\
\text { Republic of Korea (KOR), Singapore (SGP), } \\
\text { Spain (ESP), Sweden (SWE), Switzerland (CHE), } \\
\text { and the United Kingdom (GBR). }\end{array}$ & $\begin{array}{l}8 \text { economies: Brazil (BRA), Colombia (COL), Malaysia } \\
\text { (MYS), Mexico (MEX), Russia (RUS), South Africa } \\
\text { (ZAF), Thailand (THA), and Turkey (TUR). }\end{array}$ \\
\hline 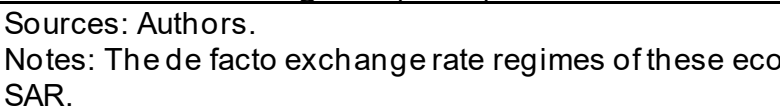 & \\
\hline
\end{tabular}

\begin{tabular}{|c|c|c|c|c|c|c|c|}
\hline \multicolumn{8}{|c|}{ Table A2. The Number of Firms by Financial Industry and Country } \\
\hline Country & Banks & Insurance & Real Estate & $\begin{array}{c}\text { Asset } \\
\text { Management }\end{array}$ & $\begin{array}{l}\text { Investment } \\
\text { Banking }\end{array}$ & Others & $\begin{array}{l}\text { Grand } \\
\text { Total }\end{array}$ \\
\hline AUS & 8 & 3 & 17 & 4 & 2 & 3 & 37 \\
\hline AUT & 4 & 2 & 5 & & & & 11 \\
\hline BEL & 2 & 1 & 9 & 2 & & 4 & 18 \\
\hline BRA & 6 & 2 & 12 & 1 & 1 & 1 & 23 \\
\hline CAN & 9 & 9 & 22 & 13 & 1 & 3 & 57 \\
\hline $\mathrm{CHE}$ & 8 & 5 & 8 & 8 & 3 & 2 & 34 \\
\hline$\overline{C O L}$ & 7 & & & 1 & & 2 & 10 \\
\hline DEU & 6 & 5 & 26 & 8 & 1 & 2 & 48 \\
\hline ESP & 7 & 2 & 14 & 1 & & 2 & 26 \\
\hline FIN & 1 & 1 & 3 & & & 1 & 6 \\
\hline FRA & 8 & 6 & 22 & 4 & 2 & 5 & 47 \\
\hline GBR & 7 & 11 & 37 & 21 & 4 & 4 & 84 \\
\hline HKG & 6 & 2 & 72 & 6 & 5 & 8 & 99 \\
\hline IRL & 3 & & & & & & 3 \\
\hline ISR & 4 & 4 & 17 & & & 3 & 28 \\
\hline ITA & 12 & 5 & 5 & 4 & 1 & 2 & 29 \\
\hline JPN & 42 & 8 & 63 & 3 & 10 & 13 & 139 \\
\hline KOR & 7 & 7 & 1 & 2 & 9 & 2 & 28 \\
\hline MEX & 4 & & 5 & 1 & & 1 & 11 \\
\hline MYS & 7 & & 15 & & & 1 & 23 \\
\hline NLD & 1 & 2 & 8 & & 2 & 3 & 16 \\
\hline PRT & 3 & & & & & & 3 \\
\hline RUS & 7 & 1 & 5 & & & 2 & 15 \\
\hline SGP & 3 & 1 & 33 & 1 & & 3 & 41 \\
\hline SWE & 3 & & 17 & 4 & & 6 & 30 \\
\hline THA & 6 & & 18 & & & 1 & 25 \\
\hline TUR & 9 & 1 & 8 & 1 & & & 19 \\
\hline ZAF & 5 & 6 & 19 & 2 & 2 & 6 & 40 \\
\hline Grand Total & 195 & 84 & 461 & 87 & 43 & 80 & 950 \\
\hline
\end{tabular}




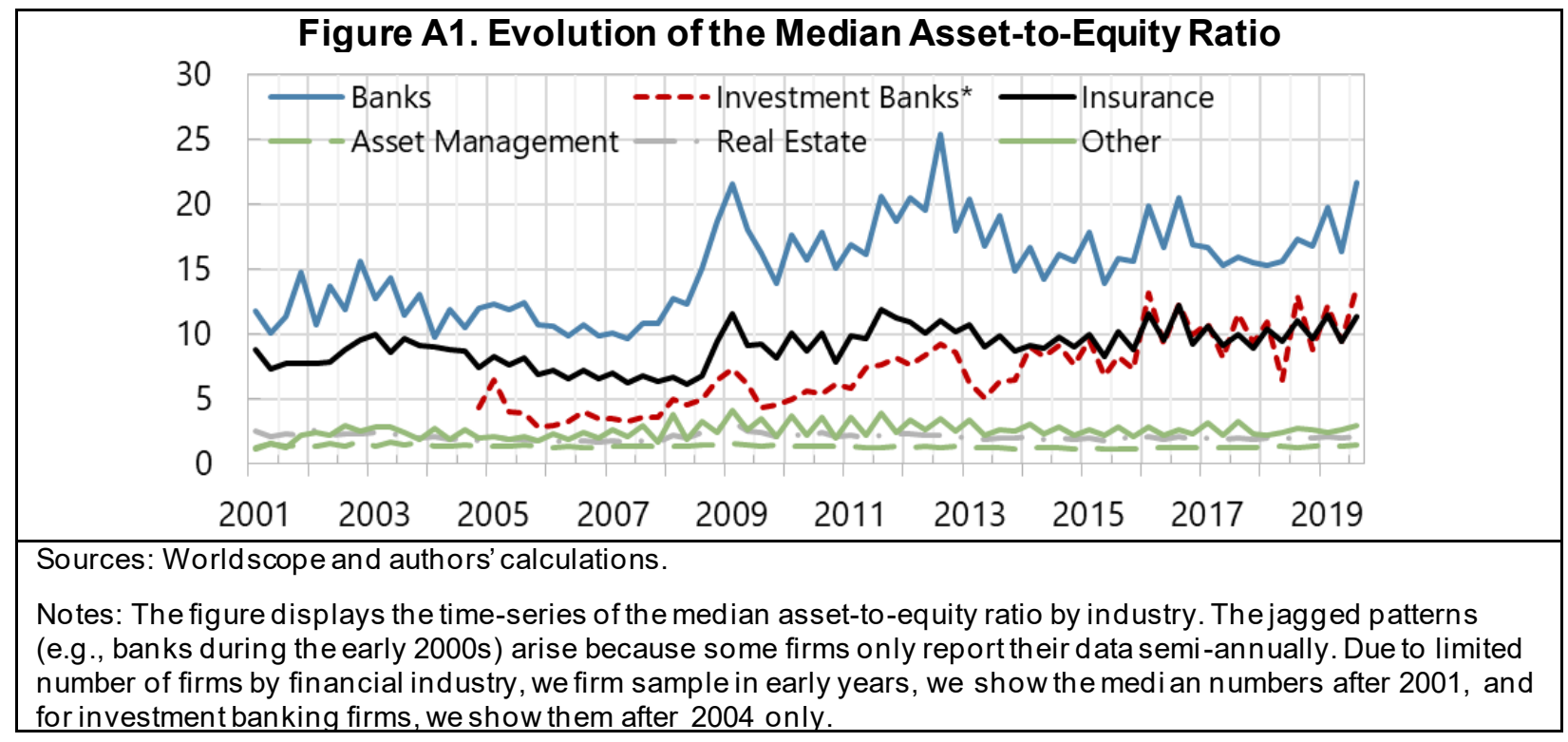

\begin{tabular}{|c|c|c|}
\hline \multicolumn{3}{|c|}{ Table A3. Definitions and Sources } \\
\hline Variable & Description & Source \\
\hline \multicolumn{3}{|c|}{ Firm-level variables } \\
\hline Total liability & $\begin{array}{l}\text { All short- and long-term obligations expected to be satisfied by } \\
\text { the company (Field 03351). }\end{array}$ & Worldscope \\
\hline $\begin{array}{l}\text { Market } \\
\text { capitalization }\end{array}$ & $\begin{array}{l}\text { The share price multiplied by the number of ordinary shares in } \\
\text { issue (Field MV). }\end{array}$ & Datastream \\
\hline Returns on assets & Net income divided by total assets (Field 08326). & Worldscope \\
\hline Returns on equity & Net income divided by total equity (Field 08301). & Worldscope \\
\hline Leverage ratio & $\begin{array}{l}\text { Calculated as the sum of total liabilities and market } \\
\text { capitalization divided by market capitalization. }\end{array}$ & $\begin{array}{l}\text { Authors' } \\
\text { computation }\end{array}$ \\
\hline \multicolumn{3}{|c|}{ Country-Level Macroeconomic Variables } \\
\hline Two-year yields & The two-year government bond yields. & $\begin{array}{l}\text { Bloomberg, } \\
\text { Datastream, Have }\end{array}$ \\
\hline Real GDP growth & The year-on-year percent change of the real GDP. & IMF's WEO \\
\hline $\begin{array}{l}\text { Growth of stock } \\
\text { price index }\end{array}$ & $\begin{array}{l}\text { The year-on-year percent change of the natural log of the main } \\
\text { stock indicator. Please see Table A4 for the list of the main } \\
\text { stock indicators. }\end{array}$ & Datastream \\
\hline Volatility index & $\begin{array}{l}\text { The square root of the } 6 \text {-month moving average over the past } 6 \\
\text { months of the squared month-on-month annualized returns. } \\
\text { Table A4 for the list of the main stock indicators. }\end{array}$ & $\begin{array}{l}\text { Datastream } \\
\text { and authors' } \\
\text { computation }\end{array}$ \\
\hline $\begin{array}{l}\text { Sovereign bond } \\
\text { rating }\end{array}$ & $\begin{array}{l}\text { Stand ard \& Poor's Local Currency Long-Term Debt Rating. The } \\
\text { values from } 1 \text { to } 22 \text { are assigned to the rating category so that a } \\
\text { higher value indicates a better rating (e.g., } 22 \text { indicates "AAA"). }\end{array}$ & Bloomberg \\
\hline
\end{tabular}




\begin{tabular}{|c|c|c|}
\hline House Price Index & House Price Index. & Datastream \\
\hline USD liabilities & $\begin{array}{l}\text { Firm-level data on the issuance of bonds and syndicated loans. } \\
\text { Assuming that debt is only repaid entirely at maturity (due to the } \\
\text { lack of repayment data), we construct the share (\%) of USD } \\
\text { liabilities in total liabilities for each firm at quarterly frequency. } \\
\text { We note that our share variable does not reflect any remaining } \\
\text { debt from the issuance before } 1998, \text { because we construct this } \\
\text { variable using the issuance data from January } 1,1998 .\end{array}$ & Thomson EIKON \\
\hline $\begin{array}{l}\text { Macroprudential } \\
\text { policy: Action } \\
\text { indicators }\end{array}$ & $\begin{array}{l}\text { Policy action indicators, which take }+1 \text { for a tightening, }-1 \text { for a } \\
\text { loosening, and } 0 \text { for a neutral or no action in each month, each } \\
\text { country, and each of the } 17 \text { macroprudential policy instruments. } \\
\text { We construct the quarterly indicators by taking the sum of the } \\
\text { monthly indicators. }\end{array}$ & $\begin{array}{l}\text { IMF's iMaPP } \\
\text { (Alam et al. 2019) } \\
\text { Website }\end{array}$ \\
\hline $\begin{array}{l}\text { Macroprudential } \\
\text { policy: Existence- } \\
\text { based indicators }\end{array}$ & $\begin{array}{l}\text { Indicators of the use of macroprudential policy instruments, } \\
\text { which take one if the instrument is in place and zero otherwise } \\
\text { in each year, each country, and each of the } 12 \text { policy } \\
\text { instruments. }\end{array}$ & $\begin{array}{l}\text { Cerutti et al. } \\
(2017) \\
\text { Website }\end{array}$ \\
\hline $\begin{array}{l}\text { Capital flow } \\
\text { management: } \\
\text { Action indicators }\end{array}$ & $\begin{array}{l}\text { Indicators of changes in CFMs, which are constructed from } \\
\text { IMF's Annual Report on Exchange Arrangements and Exchange } \\
\text { Restrictions (AREAER) report and take }+1 \text { for a tightening, }-1 \text { for } \\
\text { a loosening, and } 0 \text { for a neutral or no action in each month, } \\
\text { each country, and each category. We construct the quarterly } \\
\text { indicators by taking the sum of the monthly indicators. }\end{array}$ & $\begin{array}{l}\text { Baba et al. } \\
\text { (forthcoming) }\end{array}$ \\
\hline $\begin{array}{l}\text { Capital flow } \\
\text { management: } \\
\text { Existence-based } \\
\text { indicators }\end{array}$ & $\begin{array}{l}\text { Indicators of CFMs in place, based on the IMF's AREAER } \\
\text { report, which take a value between zero and one. They are the } \\
\text { ratio of the number of categories with a status of "yes" to the } \\
\text { total number of categories, excluding those with a status of } \\
\text { "n.a." }\end{array}$ & $\begin{array}{l}\text { Baba et al. } \\
\text { (forthcoming) }\end{array}$ \\
\hline $\begin{array}{l}\text { Foreign exchange } \\
\text { intervention: } \\
\text { Actual data }\end{array}$ & $\begin{array}{l}\text { No minal amount of foreign exchange intervention (FXI), } \\
\text { in percent of nominal GDP. Actual FXI data are available only } \\
\text { for } 12 \text { countries (Australia, Brazil, Canada, Switzerland (before } \\
2010 Q 3) \text {, Colombia, Germany (before 1999), Italy } \\
\text { (before 1999), Japan, Mexico, Russia, Turkey and United } \\
\text { Kingdom). Sources are central banks' websites and the Federal } \\
\text { Research Economic Database (FRED). }\end{array}$ & $\begin{array}{l}\text { Specified in the } \\
\text { "Description" } \\
\text { column. }\end{array}$ \\
\hline $\begin{array}{l}\text { Foreign exchange } \\
\text { intervention: Proxy }\end{array}$ & $\begin{array}{l}\text { Nominal amount of foreign exchange intervention (FXI), } \\
\text { in percent of nominal GDP. For other countries, we construct } \\
\text { the proxy by using the changes in the central bank's net foreign } \\
\text { assets adjusted for valuation changes and interest income } \\
\text { flows, taking the exact same approach in Appendix A.4. of } \\
\text { Brandao-Marques et al. (2019). Data on net foreign asset from } \\
\text { IMF's IFS, the shares of allocated reserves from IMF's COFER, } \\
\text { the composition of reserves from IMF's IRFCL, the 3-month } \\
\text { interest rates from Haver Analytics, and that a change in Total } \\
\text { Return Index from Datastream. }\end{array}$ & $\begin{array}{l}\text { Specified in the } \\
\text { "Description" } \\
\text { column, and } \\
\text { authors' } \\
\text { calculation. }\end{array}$ \\
\hline Official reserve & $\begin{array}{l}\text { Total reserves excluding gold held by monetary authorities, } \\
\text { in percent of GDP. }\end{array}$ & IMF's IFS \\
\hline Credit-to-GDP & Credit to the non-financial sector, in percent of GDP. & BIS \\
\hline US VIX & CBOE SPX Volatility Index. & Datastream \\
\hline $\begin{array}{l}\text { Policy Interest } \\
\text { Rates }\end{array}$ & $\begin{array}{l}\text { Policy rates for countries. The estimated shadow short rates are } \\
\text { used for US, UK, Japan and EU area. }\end{array}$ & $\begin{array}{c}\text { IMF's IFS, } \\
\text { Datastream, } \\
\text { Krippner (2013) } \\
\end{array}$ \\
\hline
\end{tabular}




\begin{tabular}{|c|c|c|}
\hline & & Website \\
\hline $\begin{array}{l}\text { Commodity price } \\
\text { Index }\end{array}$ & The Economist all-items commodity index. & $\begin{array}{l}\text { Global Financial } \\
\text { Data }\end{array}$ \\
\hline $\begin{array}{l}\text { Food and fuel } \\
\text { export share }\end{array}$ & Food and fuel Exports, in percent of merchandise exports. & World Bank's WDI \\
\hline Inflation & Year-on-year percent change of the Consumer Price Index. & Haver Analytics \\
\hline $\begin{array}{l}\text { Worldwide } \\
\text { governance } \\
\text { indicator }\end{array}$ & The annual indicators for the six dimensions of governance. & $\begin{array}{l}\text { World Bank } \\
\text { Website }\end{array}$ \\
\hline $\begin{array}{l}\text { Capital account } \\
\text { openness index }\end{array}$ & $\begin{array}{l}\text { An index measuring a country's degree of capital account } \\
\text { openness (KAOPEN). }\end{array}$ & $\begin{array}{l}\text { Chin and Ito } \\
\text { (2006) Website }\end{array}$ \\
\hline $\begin{array}{l}\text { Capital inflows } \\
\text { and outflows }\end{array}$ & Total Inflows and total outflows, in percent of GDP. & $\begin{array}{l}\text { IMF's Financial } \\
\text { Flows Analytics } \\
\text { (FFA) database }\end{array}$ \\
\hline Exchange Rate & $\begin{array}{l}\text { Bilateral nominal U.S. dollar exchange rate, defined as the ratio } \\
\text { of the local currency to USD. Period average. }\end{array}$ & IMF's IFS \\
\hline NEER & Nominal effective exchange rate (broad), monthly averages. & BIS \\
\hline FX volatility index & $\begin{array}{l}\text { The square root of the } 6 \text {-month moving average over the past } 6 \\
\text { months of the squared month-on-month annualized growth rate } \\
\text { of NEER. }\end{array}$ & $\begin{array}{l}\text { Datastream } \\
\text { and authors' } \\
\text { computation }\end{array}$ \\
\hline
\end{tabular}




\begin{tabular}{|c|c|c|c|}
\hline \multicolumn{4}{|c|}{ Table A4. Main Stock Indicators } \\
\hline Country & ISO-3-Code & Stock Index & $\begin{array}{c}\text { Datastream } \\
\text { Code }\end{array}$ \\
\hline Australia & AUS & S\&P/ASX 300 & ASX300I \\
\hline Austria & AUT & ATX - AUSTRIAN TRADED INDEX & ATXINDX \\
\hline Belgium & BEL & BEL 20 & BGBEL20 \\
\hline Brazil & BRA & BRAZIL BOVESPA & BRBOVES \\
\hline Canada & CAN & S\&P/TSX 60 INDEX & TTOSP60 \\
\hline Colombia & $\mathrm{COL}$ & BVC CAPITALIZATION & BVCCAPT \\
\hline Finland & FIN & OMX HELSINKI 25 (OMXH25) & HEX25IN \\
\hline France & FRA & FRANCE CAC 40 & FRCAC40 \\
\hline Germany & DEU & DAX 30 PERFORMANCE & DAXINDX \\
\hline Hong Kong SAR & HKG & HANG SENG & HNGKNGI \\
\hline Ireland & $\mathrm{IRL}$ & ISEQ 20 INDEX & ISECP20 \\
\hline Israel & ISR & ISRAEL TA 125 & ISTA100 \\
\hline Italy & ITA & FTSE MIB INDEX & FTSEMIB \\
\hline Japan & JPN & TOPIX & TOKYOSE \\
\hline Korea & KOR & KOREA SE COMPOSITE (KOSPI) & KORCOMP \\
\hline Malaysia & MYS & FTSE BURSA MALAYSIA KLCI & FBMKLCl \\
\hline Mexico & MEX & MEXICO IPC (BOLSA) & MXIPC35 \\
\hline Netherlands & NLD & AEX INDEX (AEX) & AMSTEOE \\
\hline Portugal & PRT & PORTUGAL PSI-20 & POPSI20 \\
\hline Russia & RUS & MOEX RUSSIA INDEX & RSMICEX \\
\hline Singapore & SGP & STRAITS TIMES INDEX L & SNGPORI \\
\hline South Africa & ZAF & FTSE/JSE TOP 40 & JSEAL40 \\
\hline Spain & ESP & IBEX 35 & IBEX35I \\
\hline Sweden & SWE & OMX STOCKHOLM 30 (OMXS30) & SWEDOMX \\
\hline Switzerland & $\mathrm{CHE}$ & SWISS MARKET (SMI) & SWISSMI \\
\hline Thailand & THA & BANGKOK S.E.T. & BNGKSET \\
\hline Turkey & TUR & BIST NATIONAL 100 & TRKISTB \\
\hline United Kingdom & $\overline{\text { GBR }}$ & FTSE 100 & FTSE100 \\
\hline
\end{tabular}




\begin{tabular}{|c|c|}
\hline \multicolumn{2}{|r|}{ Table A5. Mitigative policy variables $\left(P_{k, t}^{\text {Shock }}\right)$} \\
\hline $\begin{array}{c}\text { Macroprudential } \\
\text { policy } \\
\text { (all instruments) }\end{array}$ & $\begin{array}{l}\text { Ordered probit regressions are used to estimate the policy reaction function, } \\
\text { following Brandao-Marques et al. (2020). } \\
\text { - The dependent variable is the index of changes in all macroprudential } \\
\text { measures }\left(I_{k, t}^{M a P P}\right) \text {, which takes a value in }\{-2,-1,0,1,2\} \text {, if there are (in net } \\
\text { terms) more than one loosening measures, one loosening measure, no } \\
\text { change, one tightening measure, or more than one tightening measures, } \\
\text { respectively, in each quarter and in each country. Macroprudential policy } \\
\text { "action" data are from the IMF's iMaPP database (Alam et al. 2019), covering } \\
\text { the total of } 17 \text { instruments. } \\
\text { The regressors are the one-quarter lags of the credit-to-GDP gap and the } \\
\left.\text { house price gap, the past policy actions ( } \sum_{j=1}^{4} I_{k, t-j}^{M a P P}\right) \text {, and country fixed } \\
\text { effects. The "gap" variables are obtained as the deviation from the trend, } \\
\text { using Hamilton's (2018) ap proach with eight quarter lags. } \\
\text { The policy shock is obtained as the residual: } P_{k, t}^{S h o c k}:=I_{k, t}^{M a P P}-\widehat{E}_{t-1}\left[I_{k, t}^{M a P P}\right] \text {. }\end{array}$ \\
\hline $\begin{array}{l}\text { Macroprudential } \\
\text { policy } \\
\text { (sub-groups of } \\
\text { instruments) }\end{array}$ & $\begin{array}{l}\text { The policy shocks are also obtained using the same method for the sub-groups of } \\
\text { macrop rudential policy instruments. As in Brandao-Marques et al. (2020), among } \\
\text { the } 17 \text { categories of macroprudential instruments in the IMF's iMaPP database } \\
\text { (Alam et al. 2019), we consider the following two sub-groups. } \\
\text { - Borrower-based instruments: limits to the loan-to-value ratio (LTV) and the } \\
\text { debt-service-to-income ratio (DSTI). } \\
\text { - Financial-institution-based instruments: Countercyclical capital buffers (CCB), } \\
\text { capital conservation buffers (Conservation), capital measures (Capital), } \\
\text { leverage ratios (LVR), provisioning (LLP), limits to credit growth (LCG), loan } \\
\text { restrictions (LoanR), FX loan restrictions (LFC), liquidity requirements } \\
\text { (Liquidity), loan-to-deposit requirements (LTD), limits to FX positions (LFX), } \\
\text { reserve requirements (RR), regulations for significant institutions (SIFI). }\end{array}$ \\
\hline $\begin{array}{c}\text { Capital inflow } \\
\text { management } \\
\text { measures }\end{array}$ & $\begin{array}{l}\text { Ordered probit regressions are used to estimate the policy reaction function, } \\
\text { following Brandao-Marques et al. (2020). } \\
\text { - The dependent variable is the index of changes in capital inflow measures } \\
\left(I_{k, t}^{C F M}\right) \text {, which takes a value in }\{-2,-1,0,1,2\} \text {, if there are (in net terms) more } \\
\text { than one loosening measures, one loosening measure, no change, one } \\
\text { tightening measure, or more than two tightening measures, respectively, in } \\
\text { each quarter and in each country. CFM "action" data are from Baba et al. } \\
\text { (forthcoming). } \\
\text { The regressors are the one-quarter lags of (1) the log of the VIX, (2) the } \\
\text { change in the U.S. shadow rate, (3) the interaction term of the log of the } \\
\text { commodity price Index and the dummy variable for commodity exporters (the } \\
\text { share of food and fuel exports in merchandise exports is greater than } \\
30 \text { percent), (4) inflation, (5) real GDP growth, (6) official reserves in percent } \\
\text { of GDP, (7) the average of the six indexes from the World Bank's Worldwide } \\
\text { Governance Indicators, (8) the capital account openness index by Chin and } \\
\text { Ito (2006), (9) capital inflows in percentage of GDP, (10) capital outflows }\end{array}$ \\
\hline
\end{tabular}




\begin{tabular}{|l|l|}
\hline & $\begin{array}{c}\text { in percentage of GDP, (11) the interaction term of the rate of the change in } \\
\text { the nominal exchange rate against USD and its volatility index, (12) the } \\
\text { interest rate differential against U.S. shadow rate, and (13) country fixed } \\
\text { effects. } \\
\text { The policy shock is obtained as the residual: } P_{k, t}^{S h o c k}:=I_{k, t}^{C F M}-\hat{E}_{t-1}\left[I_{k, t}^{C F M}\right] . \text { It is } \\
\text { constructed for all inflow measures, and for its sub-category of inflow measures } \\
\text { targeted at three asset categories (Debt, Money Market, and Financial Credits). }\end{array}$ \\
\hline $\begin{array}{l}\text { Foreign exchange } \\
\text { intervention }\end{array}$ & $\begin{array}{l}\text { OLS regression is used to estimate the policy reaction function, following } \\
\text { Brandao-Marques et al. (2020). } \\
\text { The dependent variable is the FXI in percent of GDP. We use the actual } \\
\text { data when available and the proxy otherwise. } \\
\text { The regressors are the same as those used for the CFM shock. } \\
\text { The policy shock (Phock) is obtained as the residual. A positive (negative) } \\
\text { number indicates net purchases (sales) of foreign currency. }\end{array}$ \\
\hline Sources: Authors.
\end{tabular}

\begin{tabular}{|l|l|}
\hline \multicolumn{2}{|c|}{ Table A6. Preventive policy variables $\left(P_{k, t-4}\right)$} \\
\hline $\begin{array}{l}\text { Macroprudential } \\
\text { policy }\end{array}$ & $\begin{array}{l}\text { The four-quarter lag of the share of the policy measures in place in the total } \\
\text { number of the policy categories, in percent. Macroprudential policy "existence- } \\
\text { based" indicators are from the updated dataset of Cerutti et al. (2017), covering } \\
\text { the total of 12 instruments. The share is computed for all instruments, and the two } \\
\text { sub-g roups of borrower-based (2) and financial-institution-based (10) instruments. }\end{array}$ \\
\hline $\begin{array}{l}\text { Capital inflow } \\
\text { management } \\
\text { measures }\end{array}$ & $\begin{array}{l}\text { The four-quarter lag of the "existence-based" indicators of CFMs from Baba et al. } \\
\text { (forthcoming), which is the ratio of the number of categories with a status of "yes" } \\
\text { to the total number of categories, excluding the number of categories with a status } \\
\text { of "n.a.". It takes a value between zero and one. We use the ind icator for all inflow } \\
\text { measures, and for its sub-category of inflow measures targeted at three asset } \\
\text { categories (Debt, Money Market, and Financial Credits). For robustness checks, } \\
\text { we use the "existence-based" indices by Fernández et al. (2016) available online. }\end{array}$ \\
\hline $\begin{array}{l}\text { Foreign exchange } \\
\text { intervention }\end{array}$ & The four-quarter lag of total international reserves minus gold in percent of GDP. \\
\hline Sources: Authors. & \multicolumn{2}{|l}{} \\
\hline
\end{tabular}




\section{REFERENCES}

Acharya, V. V., R. Engle, and D. Pierret, 2014. “Testing Macroprudential Stress Tests: The Risk of Regulatory Risk Weights," Journal of Monetary Economics, vol. 65, pp. 3653.

, L. H. Pedersen, T. Philippon, and M. Richardson, 2017. "Measuring Systemic Risk," The Review of Financial Studies, vol. 30, No. 1, pp. 2-47.

Adrian, T., and H. S. Shin, 2014. "Procyclical Leverage and Value-at-Risk," The Review of Financial Studies, vol. 27, No. 2, pp. 373-403.

, B. Nina, and S. H. Song, 2016. “On the Scale of Financial Intermediaries,” FRB of NY Staff Report No. 743.

, Erceg, J. C., Lindé, J., Zabczyk, P., Zhou, J., 2020. “A Quantitative Model for the Integrated Policy Framework," IMF Working Paper No. 20/122, International Monetary Fund, Washington, DC.

Alam, Z., A. Alter, J. Eiseman, G. Gelos, H. Kang, M. Narita, E. Nier, and N. Wang, 2019. "Digging Deeper-Evidence on the Effects of Macroprudential Policies from a New Database," IMF Working Paper No. 19/66, International Monetary Fund, Washington, DC.

Ambler, S., F. Rumler, 2019. “The Effectiveness of Unconventional Monetary Policy Announcements in the Euro Area: An Event and Econometric Study," Journal of International Money and Finance, vol. 94, pp. 48-61.

Albagli, E., L. Ceballos, S. Claro, D. Romero, 2019. “Channels of US Monetary Policy Spillovers to International Bond Markets," Journal of Financial Economics, vol. 134, Issue 2, pp. 447-473.

Araujo, J., M. Patnam, A. Popescu, F. Valencia, and W. Yao, 2020. "Effects of Macroprudential Policy: Evidence from Over 6,000 Estimates," IMF Working Paper No. 20/67, International Monetary Fund, Washington, DC.

Arce, F., J. Bengui, and J. Bianchi, 2019. "A Macroprudential Theory of Foreign Reserve Accumulation,”NBER Working Paper No. 26236 (Cambridge, MA: National Bureau of Economic Research).

Arregui, N., S. Elekdag, G. Gelos, R. Lafarguette, and D. Seneviratne, 2018. "Can Countries Manage Their Financial Conditions Amid Globalization?”, IMF Working Paper No. 18/15, International Monetary Fund, Washington, DC.

Avdjiev, S., W. Du, C. Koch, and H. S. Shin, 2019. "The Dollar, Bank Leverage and the Deviation from Covered Interest Parity," American Economic Review: Insights, vol. 1(2), pp. 193-208. 
Basu, S. E. Boz, G. Gopinath, F. Roch, and F. Unsal, 2020. “A Conceptual Model for the Integrated Policy Framework” IMF Working Paper No. 20/121, International Monetary Fund, Washington, DC.

Baba, C., R. Cervantes, S. Darbar, A. Kokenyne, and V. Zotova, Forthcoming. "New Measures of Capital Flow Restrictions - AREAER Indices.” IMF Working Paper, International Monetary Fund, Washington, DC.

Barroso, J.B.R.B., L. A. Pereira Da Silva, and A. Soares Sales, 2016. "Quantitative Easing and Related Capital Flows into Brazil: Measuring its Effects and Transmission Thannels through a Rigorous Counterfactual Evaluation," Journal of International Money and Finance, Vol. 67: 102-122

Bergant, K., F. Grigoli, N.J. Hansen, and D. Sandri, 2020. "Dampening Global Financial Shocks: Can Macroprudential Regulation Help (More than Capital Controls)?" IMF Working Paper No. 19/279, International Monetary Fund, Washington, DC.

Bhargava, A., R. Bouis, A. Kokenyne, M. Perez Archila, U. Rawat, and R. Sahay, Forthcoming, "Anatomy of Capital Controls: A New Dataset," IMF Working Paper (Washington: International Monetary Fund).

Bouis, R., A. Kokenyne, M. Perez Archila, U. Rawat, and R. Sahay, Forthcoming, "Capital Controls in Times of Crisis-Use and Effects," IMF Working Paper (Washington: International Monetary Fund).

Brandao-Marques, L., G. Gelos, M. Narita, and E. Nier, 2020. "Leaning Against the Wind: An Empirical Cost-Benefit Analysis,” IMF Working Paper No. 20/123. International Monetary Fund, Washington, DC.

Bruno, V., and Hyun Song Shin, 2015a. "Capital Flows and the Risk-Taking Channel of Monetary Policy.” Journal of Monetary Economics, Vol. 71: 119-132.

Bruno, V., and Hyun Song Shin, 2015b. "Cross-Border Banking and Global Liquidity." Review of Economic Studies, Vol. 82: 535-564.

Carare, A., and R. Tchaidze, 2005. "The Use and Abuse of Taylor Rules: How Precisely Can We Estimate Them?” IMF Working Paper No. 05/148. International Monetary Fund, Washington, DC.

Campbell. J. Y., J. Hilscher, and J. Szilagyi, 2008. "In Search of Distress Risk,” The journal of Finance, vol. 63, No.6, pp. 2899- 2939.

Cavallino, P., 2019, “Capital Flows and Foreign Exchange Intervention,” American Economic Journal: Macroeconomics, Vol. 11 (2), 127-170.

Cecchetti, S.G., T. Mancini-Griffoli, M. Narita, and R. Sahay, 2020. "U.S. or Domestic Monetary Policy: Which Matters More for Financial Stability?” IMF Economic 
Review, Palgrave Macmillan, International Monetary Fund, vol. 68(1), pp. 35-65, March.

Cerutti, E, S. Claessens, and L. Laeven, 2017. "The Use and Effectiveness of Macroprudential Policies: New Evidence," Journal of Financial Stability, Vol. 28, pp. 203-224.Diamond, D., Y. Hu, and R. Rajan, 2020. "Pledgeability, Liquidity, and Financing Cycles.” Journal of Finance, vol. 75 (1), pp. 419-461.

Chamon, M., D. Hofman, S. Lanau, U. Rawat, and M. Vari, 2019. "Effectiveness of Intervention," ed. by M. Chamon, D. Hofman, N. E. Magud, and A. Werner, Foreign Exchange Interventions in Inflation Targeters in Latin America (Washington: International Monetary Fund).

Chen, J., T. Mancini-Griffoli, and R. Sahay, 2014. "Spillovers from United States Monetary Policy on Emerging Markets: Different This Time?” IMF Working Paper WP/14/240. Washington: International Monetary Fund.

Chinn, M. D. and H. Ito, 2006. "What Matters for Financial Development? Capital Controls, Institutions, and Interactions." Journal of Development Economics, vol. 81, issue 1, pp. 163-192.

Choi, W.G., T. Kang, G. Kim, and B. Lee, 2017. "Divergent EME Responses to Global and Domestic Monetary Policy Shocks," ADB Economics Working Papers Series No. 532.

Claessens, S., S. R. Ghosh, and R. Mihet, 2013. "Macro-Prudential Policies to Mitigate Financial System Vulnerabilities.” Journal of International Money and Finance, vol. 39: $153-85$.

Cizel, J., J. Frost, A. Houben, and P. Wierts, 2019. "Effective Macroprudential Policy: CrossSector Substitution from Price and Quantity Measures," Journal of Money, Credit and Banking, vol. 51(5), pp. 1209-1235.

Cubeddu, L., S. Hannan, and P. Rabanal, 2021, "External Financing Risks: How Important is the Composition of the International Investment Position?” IMF Working Paper WP/21/20 (Washington: International Monetary Fund).

Davis, J. S., M.B. Devereux, and C. Yu, 2020. "Sudden Stops and Optimal Foreign Exchange Intervention,” NBER Working Paper No. 28079 (Cambridge, MA: National Bureau of Economic Research).

Erten, B., A. Korinek, and J. A. Ocampo, 2019. "Capital Controls: Theory and Evidence," NBER Working Paper No. 26447 (Cambridge, MA: National Bureau of Economic Research).

Farhi, E., and I. Werning, 2016. "A Theory of Macroprudential Policies in the Presence of Nominal Rigidities,” Econometrica, vol. 84(5), pp. 1645-1704. 
Fanelli, S, and L. Straub, 2020. "A Theory of Foreign Exchange Interventions," NBER Working Paper 27872 (Cambridge, MA: National Bureau of Economic Research).

Fernández, A., M. W. Klein, A. Rebucci, M. Schindler, and M. Uribe, 2016. "Capital Control Measures: A New Dataset," IMF Economic Review, Palgrave Macmillan, International Monetary Fund, vol. 64(3), pp. 548-574, August.

Finger, H, and P. Lopez Murphy, 2019. "Facing the Tides: Managing Capital Flows in Asia." IMF Departmental Paper No. 19/17, International Monetary Fund, Washington, DC.

Forbes, K.J., M. Fratzscher and R. Straub, 2015. "Capital-Flow Management Measures: What are They Good for?” Journal of International Economics, vol. 96: S76-S97.

Frankel, J., and G. Saravelos, 2012. "Can Leading Indicators Assess Country Vulnerability? Evidence from the 2008-09 Global Financial Crisis," Journal of International Economics, Vol. 87(2), pp. 216-231.

Fratzscher, M., O. Gloede, L. Menkhoff, L. Sarno, and T. Stöhr, 2019. "When Is Foreign Exchange Intervention Effective? Evidence from 33 Countries," American Economic Journal: Macroeconomics, vol. 11(1), pp. 132-56.

Galati, G., and R. Moessner, 2018. "What Do We Know About the Effects of Macroprudential Policy?" Economica, vol. 85: pp. 735-70.

Gelos, G., L. Gornicka, R. Koepke, R. Sahay, and S. Sgherri, 2019. “Capital Flows at Risk: Taming the Ebbs and Flows" IMF Working Paper No. 19/279. International Monetary Fund, Washington, DC.

Gertler, M., and P. Karadi, 2015. "Monetary Policy Surprises, Credit Costs, and Economic Activity," American Economic Journal: Macroeconomics, vol. 7, No. 1, pp. 44-76.

Ghosh, A. R., J. D. Ostry, and M. Chamon, 2016. "Two Targets, Two Instruments: Monetary and Exchange Rate Policies in Emerging Market Economies," Journal of International Money and Finance, Vol. 60, pp. 172-196.

Ghosh, A.R., J.D. Ostry, and M.S. Qureshi, 2017. "Managing the tide: How do Emerging Markets Respond to Capital Flows?” IMF Working Paper No.17/69, International Monetary Fund, Washington, DC.

Gilchrist, S., D. López-Salido, and E. Zakrajšek, 2015. "Monetary Policy and Real Borrowing Costs at the Zero Lower Bound," American Economic Journal: Macroeconomics, vol. 7, No. 1, pp. 77-109.

Hanson, S. G., and J. C. Stein, 2015. "Monetary policy and Long-Term Real Rates," Journal of Financial Economics, vol.115, Issue 3, pp. 429-448.

Holston, K., T. Laubach, and J. C. Williams, 2017. "Measuring the Natural Rate of Interest: International Trends and Determinants," Journal of International Economics, vol. 108, pp. S59-S75.

International Monetary Fund (IMF), 2020. "Toward an Integrated Policy Framework.” Policy Paper No. 2020/046, International Monetary Fund, Washington, DC. 
Kalemli-Özcan, S., 2019. “US Monetary Policy and International Risk Spillovers", Jackson Hole Symposium Proceedings.

, X. Liu, and I. Shim, 2021. "Exchange Rate Fluctuations and Firm Leverage," IMF Economic Review, Palgrave Macmillan, International Monetary Fund, vol. 69, pp. 90-121, March.

Klein, M. W., 2012. “Capital Controls: Gates versus Walls," Brookings Papers on Economic Activity (1), pp. 317-367.

Korinek, A. and D. Sandri, 2016. "Capital Controls or Macroprudential Regulation?" Journal of International Economics, 99(S1): S27-S42.

Laubach, Thomas, and John Williams, 2003, "Measuring the Natural Rate of Interest," The Review of Economics and Statistics, vol. 85, no. 4, pp. 1063-1070.

Morais, Bernardo, José-Luis Peydró, Jessica Roldán-Peña, and Claudia Ruiz, 2019. “The International Bank Lending Channel of Monetary Policy Rates and QE: Credit Supply, Reach-for-Yield, and Real Effects," Journal of Finance, vol. 74(1), pp.55-90.

Nier, E., T. T. Olafsson, and Y. G. Rollinson, 2020. "Exchange Rates, Domestic Credit and Macroprudential Policy," IMF Working Paper No. 20/187 (Washington: International Monetary Fund).

Nikolsko-Rzhevskyy, A., D. H. Papell, and R. Prodan, 2014. "Deviations from Rules-based Policy and Their Effects," Journal of Economic Dynamics and Control, vol. 49, pp. 4 17.

Obstfeld, M., 2015. "Trilemmas and Tradeoffs: Living with Financial Globalization," Central Banking, Analysis, and Economic Policies Book Series, in: Claudio Raddatz \& Diego Saravia \& Jaume Ventura (ed.), Global Liquidity, Spillovers to Emerging Markets and Policy Responses, edition 1, vol. 20, chapter 2, pp. 013-078, Central Bank of Chile.

Ostry, J.D., A.R. Ghosh, M. Chamon, and M.S. Qureshi, 2012. "Tools for Managing Financial Stability Risks from Capital Inflows." Journal of International Economics, vol. 88: 407-421.

Passari, E., and H. Rey, 2015, "Financial Flows and the International Monetary System," The Economic Journal, vol. 125, pp.675-698.

Pasricha, G. K., 2020. "Estimated Policy Rules for Capital Controls," IMF Working Paper No. 20/80 (Washington: International Monetary Fund).

Rajan, R., 2014. "Competitive monetary easing - is it yesterday once more?" speech at the Brookings Institution, 10 April.

,2019. "Rising Tide," Finance \& Development, Vol. 56, No. 2, June. Available at: https://www.imf.org/external/pubs/ft/fandd/2019/06/crossborder-capital-flowsrajan.htm 
Rey, H., 2013. "Dilemma not Trilemma: The Global Financial Cycle and Monetary Policy Independence." In Proceedings-Economic Policy Symposium-Jackson Hole, Federal Reserve Bank of Kansas City, pp. 285-333.

Rebucci, A., and C. Ma, 2019. "Capital Controls: A Survey of the New Literature,” NBER Working Paper No. 26558.

Rogers, J. H., C. Scotti, J. H. Wright, 2014. "Evaluating Asset-Market Effects of Unconventional Monetary Policy: A Multi-Country Review," Economic Policy, vol. 29, issue 80, pp. 749-799.

Swanson, E. T., and J. C. Williams, 2014. "Measuring the Effect of the Zero Lower Bound on Medium- and Longer-Term Interest Rates," American Economic Review, vol. 104, No. 10 , pp. $3154-3185$.

Tong, H., and S. J. Wei, 2019. "Endogenous Corporate Leverage Response to a Safer Macro Environment: The Case of Foreign Exchange Reserve Accumulation," NBER Working Paper No. 26545.

Zhang, L., and E. Zoli, 2016. "Leaning Against the Wind: Macroprudential Policy in Asia." Journal of Asian Economics, vol. 42, pp. 33-52. 